\title{
Provisión de clérigos en las diócesis del imperio portugués y patronato real (1514-1777). Una visión sinóptica y comparativa ${ }^{1}$
}

\author{
José Pedro Paiva ${ }^{2}$
}

Recibido: 9 de enero de 2021 / Aceptado: 13 de octubre de 2021

Resumen. Este artículo proporciona una visión de cómo se han provisto los beneficios eclesiásticos, tanto las prebendas en los cabildos como los lugares en las iglesias existentes en las diócesis portuguesas fuera de Europa. El análisis cubre el período entre la consagración definitiva del patronato real (1514) y el final del reinado del rey José I (1777), por lo que tendrá un sesgo diacrónico y sintético. Tiene un propósito comparativo, ya que no es posible comprender la dinámica del sistema creado a partir de lógicas cerradas en los límites de cada diócesis e limitadas a fenómenos de naturaleza local. Las explicaciones propuestas se basan en un amplio conjunto de fuentes documentales, incluidas las relativas a diversas instancias de la administración central de la Corona, las producidas por obispos y cabildos, y la correspondencia intercambiada entre los diferentes agentes que participan en este proceso. El argumento principal es que el patronato real fue utilizado por la Corona como instrumento de recompensa para agraciar a sus servidores, sin que esto anulara la autoridad de los obispos y su capacidad para elegir el clero capitular y diocesano.

Palabras clave. Patronato Real. Nombramiento del Clero. Imperio Portugués de Ultramar. Obispos

\section{[en] The appointment of clerics for the dioceses of the Portuguese Empire and the Royal Patronage (1514-1777). A synoptical and comparative approach.}

\begin{abstract}
This article provides an insight into how ecclesiastical benefits have been appointed, both in the cathedral chapters and churches in Portuguese dioceses outside Europe. The analysis covers the period between the definitive establishment of the royal patronage (1514) and the end of the reign of King Joseph I (1777), so it will have a diachronic and synthetic bias. It assumes a comparative perspective, since it is not feasible to understand the dynamics of the system created based on logics internal to each diocese and framed only by phenomena of a local nature. We will use a set of sources, which include those relating to various bodies of the central administration of the Crown, those produced by the prelates and the cathedral chapters, letters exchanged between different agents involved in this process. The argument that will be sought is that the royal patronage was used by the Crown as a tool to grace servants with bounties (mercedes), without annulling the authority of the bishops and their ability to choose canons and other diocesan clerics.
\end{abstract}

Key-words. Royal Patronage. Appointment of the Clergy. Portuguese Overseas Empire. Bishops.

1 Investigación desarrollada en el proyecto PTDC/HAR-HIS/28719/2017, Religión, Administración y Justicia Eclesiástica en el Imperio Portugués (1514-1750) - ReligionAJE -, aprobado en el ámbito de la convocatoria de financiación de proyectos de investigación científica y desarrollo tecnológico en todos los ámbitos científicos, cofinanciado por el FEDER - Fondo Europeo de Desarrollo Regional, a través de COMPETE, Programa Operativo Competitividad e Internacionalización (POCI) y por fondos nacionales a través de FCT - Fundación para la Ciencia y la Tecnología y H2020.

2 Universidade Coimbra

ORCID: http://orcid.org/0000-0001-5312-1138

Email: lejpaiva@fl.uc.pt 
Sumario: Introducción. Expansión de la red diocesana y transferencia de la elección del clero al episcopado. Concursos según el modelo del tridentino y mercedes reales. Impactos de la integración de portugal en la monarquía hispánica. Largos períodos de sede vacante, refuerzo del papel de la mesa da consciência e ordens, mantenimiento de las prerrogativas de los obispos. Se amplía el dominio del centro político y las provisiones sin concurso. Consideraciones finales. Bibliografía.

Como citar: Paiva, J. P. (2021). Provisión de clérigos en las diócesis del imperio portugués y patronato real (1514-1777). Una visión sinóptica y comparativa, en Cuadernos de Historia Moderna, 763-799.

\section{Introducción}

La historiografía sobre la propagación del catolicismo en el mundo extra-europeo durante la modernidad ha exaltado el papel del clero regular y, en general, ha minusvalorado el del clero secular. De hecho, especialmente en el caso del imperio portugués de ultramar, ha habido pocos estudios que hayan prestado atención al clero diocesano en la estructuración de la Iglesia Católica, y aún menos a los papeles que ha desempeñado en la difusión del catolicismo entre las poblaciones no cristianas y en la configuración de las sociedades coloniales. Asimismo, algunos historiadores, especialmente en Brasil, han sostenido que el llamado patronato real, y la interferencia de la Corona en el funcionamiento de la Iglesia, condicionaba fuertemente la acción episcopal, el clero regular e incluso la autoridad de Roma; además han considerado que dicho patronato era el responsable de la relativa inmadurez de las estructuras eclesiásticas e incluso de la desregulación de la vida clerical. Los problemas de investigación planteados en este artículo son cinco:

¿De qué manera la institución del patronato real dio forma al proceso de proveer a los clérigos, tanto en los cabildos como en las iglesias de las diócesis, en espacios tan diferentes y distantes entre sí como lo eran las islas Molucas, la costa occidental de África o el interior de Brasil?

¿Se adaptó el sistema a los diferentes territorios en los que se aplicó o, por el contrario, forjó un modelo estándar poco flexible, basado en la matriz del primer experimento probado en Goa?

¿Pueden entenderse siempre las elecciones de los clérigos bajo el patronato real como una merced real en el marco de la economía clientelar que, como bien la definió Fernanda Olival, impregnó y sostuvo la monarquía portuguesa en la Edad Moderna?

¿Factores como la naturalidad y el color de la piel han limitado el acceso a los beneficios eclesiásticos?

¿En qué medida y dentro de qué límites el sistema de provisión clerical en las diócesis de ultramar comprometió la autoridad episcopal en sus diócesis?

\section{Establecimiento definitivo del patronato real y creación de la diócesis de funchal}

A partir de 1420, el Papado concedió a los monarcas portugueses y a la Orden de Cristo múltiples privilegios relacionados con el gobierno eclesiástico de los territorios que los portugueses alcanzaron y conquistaron en espacios extraeuropeos, desde 
el mundo atlántico hasta $\mathrm{Asia}^{3}$. En el período que nos ocupa, este ciclo terminó el 30 de diciembre de 1551, cuando, por la bula Praeclara Charissimi in Christi, el Papa concedió a los reyes de Portugal, "a perpetuidad", la administración de los maestrazgos de las tres Órdenes Militares, es decir, la Orden de Cristo, Avis y Santiago, prerrogativa de la que ya habían gozado los monarcas Manuel I y Juan III, aunque provisionalmente ${ }^{4}$.

Mientras, el 7 de junio de 1514, el Papa León X, por la bula Dum fidei, consagró definitivamente el derecho de patronato real sobre todas las iglesias del imperio portugués de ultramar. A través de ella, la primera en la que se utilizó la expresión "derecho de patronato", el Papado concedió a la Orden de Cristo, de la que el monarca portugués era ya gobernador, plena jurisdicción espiritual sobre las iglesias existentes y las que se construyeran en los territorios conquistados a los "infieles". Al mismo tiempo, concedió al rey Manuel I y a sus sucesores, como monarcas, el "ius patronatus et presentadi" (derecho de patronato y presentación) de estas igle$\operatorname{sias}^{5}$. El derecho de patronato, instituto jurídico utilizado desde el siglo V, consistía en un conjunto de privilegios (honoríficos, presentación del clero de las iglesias a las autoridades eclesiásticas, cobro de rentas) y cargos (construcción y defensa de las iglesias, suministro de objetos de culto, garantía de pago al clero) que la Iglesia romana atribuía, como recompensa por los servicios prestados, a los fundadores, constructores y dotadores de iglesias o beneficios eclesiásticos. A través de esta serie de bulas papales, estas prerrogativas se concentraron en el monarca y se aplicaron a todos los territorios extraeuropeos que alcanzaron los portugueses ${ }^{6}$.

Pocos días después de la promulgación de la bula que acabamos de mencionar, el 12 de junio, ahora por la bula Pro excellenti praeeminentia, a petición del mismo don Manuel I al Papa, se fundó la primera diócesis creada por los portugueses fuera del

Esta dinámica comenzó con la bula In apostolicae dignitatis specula, de 25 de marzo de 1420, por la cual Enrique el Navegante, hijo del rey Juan I, fue nombrado, entonces de forma temporal, administrador de la Orden de Cristo, aunque no era siquiera clérigo, véase Jacques, R.: De Castro Marim à Faifo. Naissance et development du padroado portugais d'Orient des origines à 1659, Lisboa, Fundação Calouste Gulbenkian, 1999, p. 19.

$4 \quad$ La bula se publicó en Corpo Diplomático Portuguez contendo os actos e relações políticas e diplomáticas de Portugal com as diversas potencias do mundo desde o século XVI até aos nossos dias, Lisboa, Typographia da Academia Real das Sciencias e Imprensa Nacional, 1887, tomo VII, pp. 90-100.

Esta bula se publicó en ibidem, tomo I (1862), pp. 254-257.

6 Los estudios más detallados y rigurosos de este largo proceso de establecimiento del patronato real y de los documentos pontificios que lo conforman son Jacques, op. cit. (nota 1); De Witte, Ch. M.: "Les bulles pontificales et l'expansion portuguaise au XVème siècle”, extrait de la Revue d'Histoire Ecclésiastique, Louvain, 1958, y De Witte, Ch. M.: Les lettres papales concernant l'expansion portuguaise au XVIe siècle, [s.1.], Nouvelle Revue de Science Missionaire, 1986. Para tener una visión completa del proceso de establecimiento del patronato real y los problemas y desafíos que planteó hasta finales del siglo XVIII es imprescindible verse Xavier, Â. Barreto y Olival, F.: "O padroado da coroa de Portugal: fundamentos e práticas", en Xavier, Â.; Palomo, F. y Stumpf, R. (org.): Monarquias Ibéricas em Perspectiva Comparada (séculos XVI-XVIII): dinâmicas imperiais e circulação de modelos administrativos, Lisboa, Imprensa de Ciências Sociais, 2018, pp. 123-160, aunque este estudio no menciona explícitamente la bula Dum fidei. Para una visión sintética, que incluye un análisis comparativo con el patronato real de los monarcas de Castilla, véase Paiva, J. P.: "1514. Uma religião para o mundo. Padroado régio e uma diocese pluricontinental”, en Fiolhais, C.; Franco, J. E. y Paiva, J. P. (dir.): História Global de Portugal, Lisboa. Temas e Debates, 2020, pp. 353-359. También es de gran utilidad, especialmente para el estudio de los impactos en el patronato real resultantes de la creación de la Congregación Romana de Propaganda Fide (1622) Pizzorusso, G.: "Il Padroado régio Portoghese nella dimensione "globale" della Chiesa Romana. Note Storico-Documentarie con particolare riferimento al Seicento", en Pizzorusso, G., Platania, G. y Sanfilippo, M. (a cura di): Gli archivi della Santa Sede come fonte per la storia del Portogallo in Età Moderna. Studi in memoria di Carmen Radulet, Viterbo, Sette Città, 2012, pp. 157-199. 
espacio europeo y africano ${ }^{7}$. Era el obispado de Funchal, en la isla de Madeira, cuyos territorios se extendieron por los archipiélagos del Atlántico (Madeira, Azores, Cabo Verde y Santo Tomé), la costa occidental de África, Brasil y Asia, constituyendo la diócesis más extensa que jamás haya existido ${ }^{8}$. El diploma pontificio de erección de la diócesis de Funchal aclara cómo se tramitaría el derecho de presentación de los beneficios eclesiásticos. Era ahora competencia del rey de Portugal presentar al Papa a los obispos de la diócesis, lo que resultaba de lo estipulado en la Dum fidei. Le competía, además, en su calidad de gobernador de la Orden de Cristo, la provisión de todos los beneficios eclesiásticos infra-episcopales, desde las dignidades, canonjías y capellanías de los cabildos de la catedral hasta las vicarías y cualquier otro ${ }^{9}$. Esta bula representa un claro refuerzo del poder de la Corona y limita las prerrogativas del vicario de la Orden de Cristo, en convergencia con las políticas que don Manuel I venía promoviendo tendentes a aumentar su tutela sobre la Iglesia y sus ingresos ${ }^{10}$. Además, la bula de creación de la diócesis de Funchal estableció lo que algunos historiadores han llamado un doble patronato, es decir, real en lo que se refiere a la presentación del obispo, y magistral en lo que se refiere al nombramiento de los miembros del cabildo y otros beneficios, pero ambos en manos del mismo titular ${ }^{11}$.

¿En un imperio geográficamente tan distante y con espacios tan variados, cómo administraron el patronato real los reyes de Portugal y lo aprovecharon para premiar sus clientelas?

Antes de la creación de la diócesis de Funchal, ya era don Manuel I, en su calidad de "regidor y gobernador" de la Orden de Cristo, quien presentaba los vicarios de las iglesias al vicario de la Orden de Cristo, con sede en Tomar, entonces titular de la jurisdicción espiritual en los territorios de ultramar, a excepción de las diócesis de Ceuta, Tánger y Safim, que ya tenían obispos. El vicario de Tomar, tras recibir la elección real, confirmaba al beneficiario y lo colaba (es decir, le confería el beneficio); en la carta de confirmación debía dejar claro que la presentación había sido realizada por don Manuel I. Este procedimiento se demostró claramente en el caso del nombramiento del vicario de la iglesia de Caniço, en $1510^{12}$.

En 1513, justo antes de la erección de la diócesis de Funchal, don Manuel I cambió este procedimiento en el caso del clero a las parroquias de esa isla. Dada la distancia de los territorios en los que tenía que operar, a lo que añadió la "gran confianza" que depositó en Nuno Cão, vicario de la iglesia principal de Funchal, y

En el norte de África hay una diócesis en Tánger desde 1469, véase De Witte, op. cit. (nota 6, 1958), p. 31, además de otras que, a pesar de no ser de fundación portuguesa, fueron, en esta época, gobernadas por obispos presentados por los reyes de Portugal (Ceuta y Safim).

$8 \quad$ La bula se publicó en Corpo Diplomático Portuguez, op. cit. (nota 4), tomo I, pp. 257-260.

$9 \quad$ Esta bula se publicó recientemente en traducción portuguesa, aunque con lapsus ocasionales, véase Morna, O. M. de Freitas: As bulas de criação da diocese do Funchal, Funchal, Secretaria Regional da Economia, Turismo e Cultura, 2015, en especial pp. 7-8. La importancia de esta bula sobre la provisión de beneficios infra-episcopales ha sido muy bien entendida por Veiga, E. de Andrade: Os párocos no Brasil no período colonial. 1500-1822, Salvador, Universidade Católica de Salvador, 1977, p. 22.

10 Paiva, J. P.: Os bispos de Portugal e do império. 1495-1777, Coimbra, Imprensa da Universidade de Coimbra, 2006, pp. 38-44.

11 De Witte, op. cit. (nota 6, 1986), p. 111, seguido por Figueirôa-Rêgo, J. de y Olival, F.: "Cor da pele, distinções e cargos: Portugal e os espaços atlânticos portugueses (séculos XVI a XVIII)”, Tempo, 15, 30 (2011), p. 132 y, más recientemente, Xavier y Olival, op. cit. (nota 6), p. 130.

12 Costa, B. Abreu da: $O$ estado eclesiástico na Madeira: o provimento de benefícios (séculos XV-XVII), [s.1.], [s.n.], 2013 (“dissertação de mestrado em História”, Universidad de Coimbra), p. 81. 
considerando que estaría mejor capacitado para evaluar y examinar las cualidades de los posibles candidatos a estos puestos, el rey delegó en él la elección de los clérigos. Estos serían indicados al monarca, quien presentaría al elegido al vicario de la Orden de Cristo en Tomar, para que lo confirmase y colase ${ }^{13}$. Tras esta decisión se percibe la preocupación por las distancias físicas, la confianza en cierto individuo elegido por el monarca, en este caso un miembro de la Orden de Cristo, y la preocupación por las cualidades del clero para que las funciones clericales se cumpliesen correctamente. En la carta, el rey incluso explicó cómo se debían llevar a cabo los exámenes. Además, este procedimiento tendrá una enorme longevidad, aunque con múltiples cambios de protagonistas y de instituciones involucradas.

Mediante el establecimiento del patronato real y la bula de creación de la diócesis de Funchal, la Corona pasó a contar con la prerrogativa de indicar a las autoridades eclesiásticas competentes (al Papa en el caso de los obispos, y a los obispos en lo que respecta a los beneficios infra-episcopales) los eclesiásticos que debían ser provistos. En la práctica, la bula modificó los protagonistas responsables de la provisión de los beneficios y creó un nuevo organismo, el cabildo, para el que debían nombrarse más eclesiásticos. Sin embargo, se mantuvo el sistema preexistente en lo que respecta al reclutamiento de vicarios de las iglesias, y el cabildo se dotó inicialmente por medio de la transferencia de freires de la Orden de Cristo que ya eran beneficiados en la iglesia principal de Funchal, mientras que el lugar de deán recayó en el citado Nuno Cão. El primer obispo de la diócesis, Diogo Pinheiro, también pertenecía a la Orden de Cristo, además de tener vínculos con la Casa de Braganza, lo que demuestra que don Manuel I fue prudente y cauteloso en la gestión de este proceso de transición institucional entre la Orden de Cristo y el nuevo obispado ${ }^{14}$.

Como el primer obispo de Funchal era un cortesano que nunca residió en su diócesis, en consonancia con el patrón entonces en boga ${ }^{15}$, ya en abril de 1515, el rey reiteró que debían mantenerse los procedimientos de nombramiento de vicarios que había aclarado dos años antes. Así, el ahora decano Nuno Cão estaba obligado a enviar un certificado del proceso de examen del elegido, para que el monarca pudiera presentarlo, si así lo deseaba, una práctica que también se adoptaría en relación con la provisión de dignidades y canonjías ${ }^{16}$. Hasta $1529-30$, es posible que parte de los nombrados para el cabildo y las parroquias de Funchal siguieran siendo freires de la Orden de Cristo, situación que cambió desde esa fecha debido a la reforma del Convento de Tomar promovida por el rey don Juan III, que impuso la obligación de la clausura a los nuevos miembros de la institución, impidiéndoles disputar los beneficios de las iglesias de ultramar ${ }^{17}$.

Sin duda, los cambios de jurisdicción provocados por las bulas de 1514 provocaron dudas de las que hay ecos en la India. Una carta del vicario de Cananor al rey don

13 Albalá de don Manuel I para la elección de clérigos en el obispado de Funchal, 20 de marzo de 1513, en Arquivo Nacional Torre do Tombo, Lisboa (ANTT), Cabido da Sé do Funchal, maço 5, doc. 17, bien analizado por Costa, op. cit. (nota 12), pp. 84-85.

14 Bethencourt, F.: “A Igreja”, en Bethencourt, F. y Chaudhuri, K. (dir.): História da Expansão Portuguesa, Lisboa, Círculo de Leitores, 1998, vol. 1, pp. 370 y 374, y Paiva, op. cit. (nota 10), pp. 297-298.

15 Paiva, J. P.: "Les évêques à la cour du roi sous Manuel I Ir et Jean III du Portugal (1495-1577)", Revue d'Histoire Ecclésiastique, 111/1-2 (2016), pp. 61-79.

16 ANTT, Cabido da Sé do Funchal, maço 5, doc. 28, ya bien entendido por Costa, op. cit. (nota 12), p. 87 y Xavier y Olival, op. cit. (nota 6), p. 131.

17 Figueirôa-Rêgo e Olival, op. cit. (nota 11), p. 132. 
Juan III, escrita en 1523, aclaraba que el monarca había establecido un regimiento, a semejanza de lo que había hecho en Funchal, explicando cómo se debían proveer los vicarios de las fortalezas de la India, hasta entonces nombrados por períodos de tres años, lo que fue alterado por esta nueva disposición. La misma carta prueba que era el rey el que presentaba a los vicarios, como ocurrió en el caso de este de Cananor, que después eran confirmados por el obispo de Funchal, que cobraba las tasas de chancillería por la emisión de estas cartas de confirmación y colación. Sin embargo, la inexistencia de registros efectivos de las mercedes reales suponía que más de una persona fuese designada para el mismo beneficio, como sucedió en Cananor ${ }^{18}$.

En el caso de Brasil, cuyo modelo de ocupación era diferente del de la India, el territorio estaba bajo la jurisdicción espiritual del obispo de Funchal cuando, a partir de la década de 1530, se comenzaron a crear las capitanías. Sin embargo, como no había un obispo residente, ni un vicario de la Orden de Cristo, la provisión de clérigos siguió el sistema adoptado en Madeira antes de 1514, aunque con adaptaciones. Así, el rey, como gobernador de la Orden de Cristo, elegía a los clérigos cuando éstos aún se encontraban en el reino. Eran entonces examinados por el deán de la capilla real y obispo de S. Tomé, don Diogo Ortiz de Villegas, teólogo de la corte y figura cercana al monarca, y luego confirmados y colados por el obispo de Funchal, entonces residente en la corte.

Hay ejemplos de ello, desde 1534 en adelante, al menos para Olinda, San Vicente, Espíritu Santo y Porto Seguro. Así se hizo en octubre de 1534, cuando, estando en Évora, el rey comunicó al proveedor de los almacenes de la Casa de la India que había enviado un vicario y cuatro capellanes a Olinda, y fijaba para el primero un pago de 15.000 reales al año y dos esclavos, estos últimos proporcionados por la Casa de la India, lo que demuestra que el sustento de los clérigos de la Iglesia de ultramar también se fundamentaba en la trata de esclavos ${ }^{19}$. En el caso del vicario y capellanes de la capitanía de San Vicente, nombrados en 1535, el rey aclaró que "el arzobispo de Funchal, primado de las Indias, mi querido sobrino, proveyó en dicho vicariato" a Simón de Lucena, "según la forma de la carta que lleva", mostrando de manera inequívoca que fue el obispo de Funchal quien presentó y coló a los primeros vicarios $\mathrm{y}$ curas que actuaron en esos territorios ${ }^{20}$. Cuando las iglesias se quedaban sin párroco, el rey delegó su poder de presentación al proveedor del Tesoro Real residente en Brasil a fin de evitar que las poblaciones careciesen de asistencia religiosa y superar, así, la barrera que imponían las distancias. Así sucedió, por ejemplo, en junio de 1550, cuando el proveedor António Cardoso de Barros, por ser la iglesia de Santos sin vicario, "encargó" al Padre Fernão Carapeto la función, por "ser apto" y "tener cualidades y confianza en él", hasta que el monarca le proveyó definitivamente ${ }^{21}$.

Este proceso de provisión en los beneficios bajo la tutela de la diócesis de Funchal era distinto del que se aplicaba en los territorios americanos conquistados por Castilla. Allí, al principio, existía un sistema muy informal en el que el clero llegaba y administraba los sacramentos a los que vivían en la zona bajo el dominio de un encomendero (un laico con amplios privilegios sobre ciertas tierras), que debía ga-

18 Rego, A. da Silva: Documentação para a História das Missões do Padroado Português do Oriente. Índia, Lisboa, Agência Geral das Colónias, 1951, vol. II, pp. 14-17.

19 Documentos históricos. Provimentos seculares e ecclesiásticos 1540-1559, Rio de Janeiro, Ministério da Educação e Saúde - Biblioteca Nacional, 1937, vol. XXXV, pp. 42-44.

$20 \quad$ Ibidem, pp. 73-74.

21 Ibidem, pp. 80-81. 
rantizar la atención espiritual de las poblaciones nativas, para lo cual estaba obligado a contratar sacerdotes. Sólo a partir de 1530 la competencia de elegir y nombrar párrocos fue transferida para los obispos ${ }^{22}$.

\section{Expansión de la red diocesana y transferencia de la elección del clero al episcopado}

La expansión de la red diocesana en el imperio de ultramar, impulsada por la Corona en un momento en el que una dinámica similar se había intensificado también en la América española ${ }^{23}$, que no puede sino ponerse en relación, condujo a la fragmentación del gigantesco obispado de Funchal y a la constitución de cuatro nuevas diócesis en 1533-34: Cabo Verde, Angra (Azores), S. Tomé y Goa. Hay dos aspectos de este proceso que merecen ser destacados.

El primero es la garantía dada por el rey al primer obispo de S. Tomé, en una carta de octubre de 1535, de que "el derecho de patronato y presentación a las dignidades, canonjías y otros beneficios, con o sin cura [de almas] de dichos obispados era del maestre o gobernador de la mencionada Orden de Cristo, así de los beneficios que ahora se creasen" como los que se instituyesen en el futuro ${ }^{24}$. En otras palabras, el rey Juan III quería asegurarse de que no caían en el olvido los privilegios conseguidos en Roma unos veinte años antes en relación a Funchal y que se mantenía el sistema del doble patronato: él, como rey, presentaría a los obispos y, como gobernador de la Orden de Cristo, a los demás beneficiados.

En segundo lugar, como se afirma en la bula de erección de la diócesis de Cabo Verde, el obispo y "sus sucesores tendrán en su diócesis la misma jurisdicción episcopal, autoridad y poder que cualquier otro obispo de Portugal", es decir, el papado destacaba el lugar central del prelado en los territorios bajo su tutela, independientemente del poder real que se deriva del patronato real ${ }^{25}$. Además, en este contexto, por primera vez un obispo titular de una de estas diócesis de ultramar fue a residir en el obispado, el fraile franciscano Juan de Albuquerque, prelado de Goa, adonde llegó en septiembre de 1538. Fue en Goa donde se diseñó un modelo para la provisión del clero secular, en el contexto del patronato regio y con un obispo residente, ya que en este momento los obispos no residían en Angra, Cabo Verde y Santo Tomás, lo que hace suponer que confirmarían en el propio reino a los clérigos presentados por el rey.

La bula de fundación de la diócesis de Goa, hacía explícita la obligación de crear un cabildo con las respectivas dignidades y canónigos, y reiteraba que el derecho de presentación del obispo, del cabildo y de todos los beneficiados era del rey ${ }^{26}$. En este

22 Schwaller, J. F.: The Church and Clergy in Sixteenth-Century Mexico, Albuquerque, University of New Mexico Press, 1987, p. 69.

23 Fernández Terricabras, I.: "El Patronato Real en la América Hispana: fundamentos y prácticas", en Xavier, Â.; Palomo, F. y Stumpf, R. (org.): Monarquias Ibéricas em Perspectiva Comparada (séculos XVI-XVIII): dinâmicas imperiais e circulação de modelos administrativos, Lisboa, Imprensa de Ciências Sociais, 2018, pp. 113-114.

24 Carta publicada en Brásio, A.: Monumenta Missionaria Africana. Africa Ocidental (1532-1569), Lisboa, Agência Geral do Ultramar, 1953, vol. II, pp. 49-50.

25 Propuesta ya sugerida por Witte, op. cit. (nota 6, 1986), p. 96.

26 Witte, op. cit. (nota 6, 1986), pp. 98-99. 
caso, sin embargo, las enormes distancias entre la India y Portugal, la dificultad de reclutar clérigos y la confianza real en el obispo dieron lugar a una nueva práctica. El 11 de marzo de 1538, cuando Albuquerque estaba a punto de embarcarse para su diócesis, Juan III le concedió el derecho de "elegir" a todos los vicarios, dignidades y miembros del capítulo, y de confirmarlos ${ }^{27}$. Otro documento, escrito desde la India para el Consejo Ultramarino en 1663, pero que se refiere a estos años del gobierno de Albuquerque, confirma que los elegidos por el obispo eran entonces indicados a los virreyes o gobernadores para que éstos presentasen "todos los beneficios, dignidades, canonjías y demás beneficios curados de los obispados y arzobispados de la India en sujetos eclesiásticos que elegían por más dignos, sin contradicción ni alteración alguna, por órdenes particulares y expresas que tenían de los señores reyes de Portugal, gran maestre de este Maestrazgo de Cristo" 28 . Cuando la diócesis estaba vacante, es decir, sin obispo, era el virrey o gobernador quien elegía y presentaba, en nombre del rey, y el cabildo lo confirmaba. Así se manifiesta en una petición del virrey Afonso de Noronha (1550-54), y se demuostra con la carta de presentación de la prebenda de tesorero del cabildo de la diócesis de Cochin, expedida en favor de un sacerdote de Montijo (Portugal) que en la India ya había hecho varios servicios al rey ${ }^{29}$.

Al mismo tiempo, desde Portugal el rey podía seguir presentando clérigos para algunos de estos lugares, pero siempre correspondía al obispo confirmarlos y darles la posesión. Y éste no dejó de mostrar que no lo haría a cualquier precio. En 1539, Albuquerque hizo una visita pastoral y encontró que el padre Diogo de Morais, elegido por el monarca como deán de la nueva catedral, "era inapto e insuficiente", además de ser un hombre "de poca paz y desconsuelo", por lo que se negó a confirmarlo 30 .

El modelo seguido en Goa se repitió en la diócesis de Salvador da Bahia (Brasil), creada en $1551^{31}$. Como se explica en la carta regia por la que el rey Juan III presentaba y recibía la confirmación papal de Pedro Fernandes como obispo, todos los beneficios infra-episcopales serían de la presentación del rey en su capacidad de administrador de la Orden de Cristo. Sin embargo, el nuevo prelado tenía el poder de crear más tarde nuevas dignidades, canonjías o beneficios si lo consideraba necesario $^{32}$. Así las cosas, incluso antes del viaje del primer obispo de Brasil, cuando aún estaba en Lisboa, el rey le presentó varios individuos, todos miembros de sus clien-

27 Esta información es proporcionada en una obra escrita por un jesuita que, a principios del siglo XVII, todavía vio en Goa un Tombo da Sé que contenía bulas y cartas regias, Gonçalves, S.: Primeira parte da história dos religiosos da Companhia de Jesus e do que fizeram com a divina graça na conversão dos infieis a nossa santa fee catholica nos reynos e provincias da India Oriental, Coimbra, Atlântida, 1957, vol. 1, p. 425.

28 Carta del cabildo de Goa en Arquivo Histórico Ultramarino, Lisboa (AHU), Conselho Ultramarino, Índia, caixa 45 , doc. 23 , fl. sin numeración.

29 Gonçalves, op . cit. (nota 27), p. 425 y AHU, Conselho Ultramarino, Índia, caixa 33, doc. 89, fl. sin numeración.

30 Véase el "Auto de protestação mandado fazer pelo bispo Juan de Albuquerque a respeito da criação no novo lugar de adaigado na Sé de Goa”, de 6 de Junio de 1539, en Rego, op. cit. (nota 18), pp. 265-268.

31 De lo que se ha expuesto se desprende que no sigo la idea de que Madeira y Angra fueron el "laboratorio" donde se diseñaron los procedimientos para la provisión de los clérigos seculares, como se sostiene en Rodrigues, A. C. y Olival, F.: "Reinóis versus naturais nas disputas pelos lugares eclesiásticos do Atlântico português: aspectos sociais e políticos (século XVIII)”, Revista de História (São Paulo), 175 (2016), p. 62. A pesar de la relevancia de los experimentos realizados allí, no se aplicó por primera vez el sistema de patronato laico, ya que en Portugal, mucho antes, hubo experimentos similares, ni tampoco fue allí donde residieron por primera vez los obispos de ultramar, situación que, como se ha demostrado, fue crítica en la definición del modelo de provisión episcopal adoptado en las diócesis de ultramar.

32 Documentos históricos, op. cit. (nota 19), pp. 117-127. 
telas, para ocupar el cabildo que se instalaría en la colonia. El prelado los examinó, los presentó y los coló ${ }^{33}$.

Desde que Pedro Fernandes llegó a Brasil, fue él quien pasó a elegir a todos los beneficiarios después de examinarlos. Hecha esta diligencia, indicaba su elección al proveedor del Tesoro Real, encargado del pago destinado a la manutención de los eclesiásticos. El proveedor, que había recibido "una carta de patente [por la que el rey] le da todo el poder que tiene para presentar las dignidades, canonjías, capellanías y curatos que se proveen en estas partes", los presentaba en nombre del rey, "como maestro y administrador perpetuo que es de la Orden y la Caballería de Nuestro Señor Jesucristo". Finalmente, con esta carta de presentación, el obispo confirmaba y daba posesión al clérigo ${ }^{34}$. El objetivo de esta práctica era evitar que los clérigos designados en Brasil tuvieran que acudir a Portugal para pedir al rey sus cartas de presentación, lo que dificultaría el buen funcionamiento de la actividad religiosa en las iglesias y parroquias.

Cabe señalar que no había ningún límite a las elecciones del obispo, ni siquiera para el lugar del deán de la catedral, la dignidad más importante del cabildo. Así queda confirmado en la carta de presentación de Fernão Pires, emitida por el proveedor del Tesoro el 22 de febrero de 1554. En ella se afirma que el obispo le había presentado una carta sellada emitida por su cancillería, por la que había "nombrado al clérigo de misa, Fernão Pires, para presentarlo en la dignidad de deán de la catedral". Por consiguiente, al haber recibido del rey Juan III poder para ello, "presentó" al mencionado eclesiástico "para la dicha dignidad de deán", en nombre de Juan $\mathrm{III}^{35}$. Con esta carta de presentación, el obispo volvía a tomar la palabra, ahora para confirmar la provisión y hacer la colación.

Esto se muestra, para dar otro ejemplo, con la confirmación, en noviembre de 1554, del capellán de la catedral Diogo Rodrigues, nacido en Vila da Feira (Portugal). En ella, el obispo certifica que el capellán se presentó ante él y le entregó "una carta de presentación escrita por el Dr. Pero Borges, provedor mor". El obispo examinó al propuesto y, considerando que el clérigo era "apto y suficiente para servir a la capellanía", llevó a cabo el ritual de colación, replicando en Brasil el acto habitual en las diócesis del reino. Así le puso un "birrete" en la cabeza y, de esta manera, lo "confirmamos en una de las seis capellanías de esta Sede, a presentación de dicho señor [el rey], a quien por derecho pertenece tal presentación como maestre y gobernador que es de la Orden y la Caballería de Nuestro Señor Jesucristo". Para atestiguar la autoridad del prelado, el documento explicitaba las obligaciones del beneficiado, que "juró en nuestras manos a los Santos Evangelios ser siempre obediente a nosotros y a nuestros sucesores (...), y cumplir y guardar todos nuestros mandamientos y los de nuestros oidores y lugartenientes (...) y guardar el Reglamento que hemos hecho en esta Sede y las Constituciones del Arzobispado de Lisboa, que ordenamos guardar en este nuestro obispado"36.

Los poderes conferidos al obispo le permitieron incluso crear nuevos beneficios, de duración precaria, que proveía libremente sin interferencia del monarca o del

33 Paiva, J. P.: “Trabalho mais para que não se pervertam os brancos do que para a conversão dos negros. Pedro Fernandes, bispo de Salvador da Bahia (1551-1556), entre Paris, Lisboa, Goa, Cabo Verde e Brasil”, Varia História, 37, 73 (2021), pp. 294-295.

34 Véase, por ejemplo, Documentos históricos, op. cit. (nota 19), pp. 186-188.

35 Ibidem, pp. 200-201.

36 Ibidem, pp. 238-242. 
proveedor. Tal fue el caso de la creación de un cura en Salvador en 1553. En esta ocasión, el prelado se dirigió al gobernador Tomé de Sousa, informándole de que el vicario de la catedral le había pedido permiso para ir a Portugal, y que era urgente nombrar un sustituto. En consecuencia, "porque en este momento esta catedral no tiene un cura, he presentado y nombrado como cura al padre Luiz Dias porque es hábito y suficiente para tal cargo (...) y lo nombro a Su Señoría para cura en la dicha catedral, y le pido que lo anote en el Libro de Registros, para que se le pague" su manutención y el gobernador resolvió favorablemente la autorización de este pago ${ }^{37}$.

Mientras tanto, en Funchal, tal vez debido a las disputas entre las parcialidades en que se dividió el cabildo cuando tuvo que elegir a los beneficiados de la catedral y otras iglesias de la isla, en marzo de 1554, Juan III reformó el sistema adoptado allí desde 1513, que, tras la muerte del vicario Nuno Cão, en torno a 1531, puso en manos de los canónigos la decisión de la elección ${ }^{38}$. Esta opción también debió ser determinada por las prácticas ya adoptadas en Goa y en Brasil, en un momento en que se preparaba la partida para el archipiélago de fray Jorge de Lemos, primer obispo titular de Funchal que residió allí, tratando de evitar que, con la llegada del prelado, surgieran disputas con el cabildo motivadas por las facultades que éste tenía para la provisión de beneficios. La orden para el cabildo fue clara y determinó que el monarca, como gobernador perpetuo de la Orden de Cristo, "presentaré a ellos [a los beneficios] a quien me parezca bien sin considerar vuestra elección"39.

Para preparar el terreno, en febrero de 1558, la reina y regente Catalina de Austria, hermana de Carlos V, determinó aplicar en Funchal el patrón ya seguido en Goa y Brasil, aunque con tres importantes salvedades que apuntaban a fortalecer la capacidad de la Corona. Así, la carta dirigida al obispo subrayaba que esta concesión era limitada en el tiempo ("hasta que yo lo haya por bien y no mande el contrario"); que la indicación del obispo no obligaba a la reina regente ("si así lo hubiere por bien, mandará expedir la carta de presentación de dicho beneficio para dicha persona o para cualquier otra que me parezca mejor"); y que se reservaba la elección del titular de la dignidad principal de la catedral, el deán ${ }^{40}$. Además, en el caso de Funchal, más cerca de Lisboa, después de que el obispo nombrara al provisto, era la reina la que expedía la carta de presentación. Un privilegio similar se le concedió al obispo de Santo Tomé, Gaspar Cão, que había vivido allí desde $1556^{41}$, y es probable que lo mismo sucediese en Cabo Verde, donde se encontraba el obispo Francisco da Cruz.

A partir de esta fecha, en Funchal y al menos en San Tomé, la mayor dignidad del cabido servía para gratificar a los clérigos que hubiesen servido a la Corona. De hecho, en 1556, cuando murió el deán de San Tomé, el obispo Gaspar Cão pidió a la reina "en este beneficio, ordene que se provea como sea servicio de Nuestro Señor y suyo". Años más tarde, en 1566, cuando el regente ya era el inquisidor general don Henrique, éste indicó para deán a un deputado de la Inquisición, lo que revela el tipo de intereses que movían estas elecciones ${ }^{42}$. Esta dinámica observada en las diócesis extraeuropeas iba de la mano de la lucha de la Corona por controlar la provisión del lugar más importante de los cabildos, que se acentuó en el reinado de Juan III

Ibidem, pp. 167-168.

Me gustaría agradecer a Bruno Costa por la información sobre la fecha de la muerte de Nuno Cão.

ANTT, Cabido da Sé do Funchal, maço 5, doc. 19, já referido por Costa, op. cit. (nota 12), pp. 88-89.

ANTT, Cabido da Sé do Funchal, maço 5, doc. 33.

Brásio, op. cit. (nota 24), vol. II, pp. 549-550.

Brásio, op. cit. (nota 24), vol. II, pp. 430 y 551. 
(1521-1557), también en las diócesis del reino, donde el rey buscaba hacerse con la prerrogativa de tales nombramientos, especialmente en las llamadas nuevas diócesis (Miranda, Portalegre, Elvas y Leiria). Sin embargo, como ya se ha demostrado, no siempre tuvo éxito, y se mantuvo el derecho de presentación de la mayoría de los deanes de Portugal en manos del papado y los obispos ${ }^{43}$.

También en estos años, la centralización de estas decisiones en la Corona se manifestó en la injerencia de un nuevo organismo en el proceso de provisión de los beneficios eclesiásticos en ultramar: la Mesa de Consciência. Esta, consejo y tribunal al mismo tiempo, había sido instituida por Juan III en 1532 con el propósito de ayudarle a decidir sobre asuntos de conciencia. Desde el decenio de 1530, se había instalado en la Mesa de Consciência un poderoso grupo de teólogos, ya conocidos como teólogos de la corte, que aconsejan al rey para resolver las controversias relativas a sus responsabilidades religiosas, incluidas las derivadas del derecho de patronato en los territorios de ultramar. Este organismo, único en el contexto europeo, se fue convirtiendo en el lugar donde se fusionaban los intereses políticos de la monarquía y el gobierno de la vida eclesiástica del reino. En 1558, la Mesa da Consciência e Ordens, designación adoptada en 1551, tuvo su primeras constituciones, signo inequívoco de la importancia que había alzancado. Aquí, además de debatir temas como la esclavitud africana, los bautismos de los amerindios, las relaciones comerciales con los mercaderes musulmanes y la creación de nuevas diócesis, también se consideraron los problemas derivados del ejercicio del derecho de patronato real ${ }^{44}$.

Alrededor de 1559, justo antes de la partida para Brasil de Pedro Leitão, segundo obispo de esa diócesis, surgieron las primeras referencias a la intervención de la Mesa de Consciência e Ordens en el proceso de provisión de beneficios eclesiásticos en las diócesis de ultramar. Cuando el prelado todavía estaba en Lisboa, la regente Catalina, "por la buena información" que el obispo le había dado de la "bondad, vida y costumbres" de Pedro da Fonseca, y después de que este hubiera sido "examinado y considerado idóneo por los diputados de la Mesa da Consciência", lo presentó al obispo para su confirmación. El mismo procedimiento se aplicó en la elección del nuevo deán, reiterando que, en Brasil, este privilegio de indicar la dignidad principal, al contrario de lo que ocurrió en Funchal, se mantuvo en el prelado ${ }^{45}$. Al mismo tiempo que el obispo recibía estos encargos, la reina, en una carta del 25 de julio de 1559, concedió al gobernador de Brasil Mem de Sá la facultad de presentar en su nombre todos los beneficios que vacasen, o que se creasen y le fueran indicados por el obispo, ya que confiaba en las buenas elecciones que haría el prelado. Esto ocurría si los clérigos ya residían en Brasil, porque, si vivían en el reino, serían presentados por el rey, después de ser examinados por la Mesa da Consciência e Ordens ${ }^{46}$.

A pesar de la intervención de la Mesa da Consciência, que se ejercería ya en las diócesis de las islas del Atlántico desde los años cincuenta, resulta evidente el deseo de no cercenar la autoridad de los obispos, por lo que la Mesa sólo intervenía en los casos en que los nombramientos se hacían en Lisboa. El siguiente obispo de Brasil,

43 Silva, H. Ribeiro da: O clero catedralício português e os equilibrios sociais do poder (1564-1670), Lisboa, Centro de Estudos de História Religiosa, 2013, especialmente pp. 99-106.

44 Marcocci, G.: A consciência de um império. Portugal e o seu mundo, sécs. XV a XVII, Coimbra, Imprensa da Universidade de Coimbra, 2012, especialmente pp. 132-144.

45 Documentos históricos. Provimentos seculares e ecclesisticos 1559-1577, Rio de Janeiro, [s.n.], 1937 , vol. XXXVI, respectivamente pp. 15-16 y 63-65.

$46 \quad$ Ibidem, pp. 42-44. 
fray António Barreiros, recibió los mismos poderes, y esta práctica todavía estaba en vigor en 1642, como lo decía Pedro da Silva en el informe de la visita ad limina que envió a Roma. Allí explicó que "el rey suele conceder al obispo de Salvador el nombramiento de las personas que se han de presentar y proveer, para que las iglesias obtengan los ministros más capaces y la dignidad episcopal la más alta autoridad" 47 . Este documento no explica quién presentaba al deán, pero, en 1603, la carta en la que se autorizaba al obispo Constantino Barradas a proveer los beneficios ya exceptuaba la presentación de esta dignidad ${ }^{48}$.

El mismo sistema se adoptó cuando Gaspar de Leão se hizo cargo de la mitra de Goa. El 12 de marzo de 1560, el regente don Henrique informó al virrey Constantino de Bragança de que, con el fin de evitar "trabajo y opresión y gastos a los clérigos que se han de proveer en las dignidades, canonjías, vicarías y cualquier otro beneficio de esa ciudad y las iglesias del mencionado arzobispado de Goa", le daba "comisión y poder pera que por mí y en mi nombre presentéis por vuestras cartas" todos los beneficios, "a los que presentaréis a los clérigos que el mencionado arzobispo, por medio de sus escritos firmados por él, nombre y declare, y no a otros, porque confío en el mencionado arzobispo". En la misma carta, el rey encargaba al arzobispo "que lo haciese así y por vuestras cartas de presentación confirme en los beneficios mencionados los que se le presentan y les pase a sus cartas de confirmación en forma, en las que hará mención expresa de cómo los confirmó a presentación mía, para la guarda y conservación de mi derecho". El regente explicaba además que este procedimiento estaría en vigor sólo mientras él lo deseara y, como en el Brasil, no habría limitación con relación al nombramiento del decano ${ }^{49}$.

Estas disposiciones tuvieron un efecto práctico. En 1567, cuando la diócesis ya estaba bajo el gobierno del obispo Jorge Temudo, se emitió en estos mismos términos la carta regia de presentación de un vicario para la iglesia de Santa Lucía, en Goa. El mismo documento certifica que en Asia se practicaba también el ritual de colación ya descrito en el caso de Brasil, atestiguando el obispo que "confirmamos en dicho vicariato en virtud de dicha presentación [que había recibido del gobernador], que le confirmamos [al beneficiado] ordinaria y canónicamente per imposición de birrete que le pusimos en la cabeza, guardando en ella las solemnidades del derecho y estilo común permitidas y exigidas, además del juramento ordinario que hizo en nuestras manos". Además, en este caso se dispone de información sobre cómo tomo posesión del beneficio el clérigo, transfiriendo a Asia la ceremonia de posesión adoptada en Portugal: "Así que ambos fueron a la iglesia de Santa Lucía (... ) y luego Manuel Rodrigues entró en la iglesia (...) y abrió y cerró la puerta principal de ella y fue a la puerta de la verja de la capilla mayor e hizo lo mismo abriendo y cerrando la puerta de la verja de la capella, y ordenó traer un libro misal de la sacristía y lo abrió y cerró; y hechos así dichos autos, dicho Manuel Rodrigues dijo que se encontraba en posesión de la iglesia". ${ }^{50}$

47 Véase, respectivamente, la carta entregada al obispo el 7 de febrero de 1576, ANTT, Chancelaria da Ordem de Cristo [Próprios], Lv. 4, fl. 25 y Arquivo Apostolico Vaticano, Roma (AAV), Congregazione Concilio, Relationes Dioecesium, vol. 712, fls. sin numeración. La cita es una traducción del latín original realizada por António Guimarães Pinto, accesible en https://www.uc.pt/fluc/religionAJE/fontes/docs/Salvador_1642_traduzida.pdf.

48 Biblioteca Nacional, Lisboa (BN), Pombalina, Códice 155, fl. 124.

49 Rivara, J. H. da Cunha: Archivo Portuguez-Oriental. Fascículo $5^{\circ}$ que contem documentos varios do século XVI. $1^{a}$ parte, Nova Goa, Imprensa Nacional, 1865, pp. 436-438.

so Ibidem, pp. 646-47 y 651 . 
Los mismos procedimientos se siguieron en Malaca, diócesis creada en 1558 a la que también acudió inmediatamente su primer obispo, fray Jorge de Santa Luzia. Un informe de la visita ad limina de 1624 confirma que era el obispo quien seleccionaba y confirmaba a los miembros del cabildo y de las parroquias, pero no se especifica si sus nombramientos requerían de la intervención del virrey o del gobernador en Goa, que presentaría en nombre del rey como gobernador de la Orden de Cristo ${ }^{51}$. Es muy probable que en la diócesis de Cochín, también constituida en 1558, se siguiera esta práctica.

En el caso del Estado de la India, muchas parroquias fueron confiadas al clero regular, lo que dio lugar a diversos procedimientos y problemas de jurisdicción con los arzobispos. De hecho, en Goa, las parroquias de las zonas de Salsete y Bardez sólo pasaron a estar bajo dominio portugués en 1543, a lo que siguió un período de cierta inestabilidad hasta 1570. A partir de 1560 se intensificó el esfuerzo por difundir el cristianismo y estas áreas fueron entregadas a los jesuitas y franciscanos para la conversión de sus habitantes ${ }^{52}$.

Previendo las dificultades que podrían surgir con los obispos, en 1567 el papa Pío $\mathrm{V}$ autorizó a los religiosos de las órdenes regulares a asumir funciones de cura de almas en las parroquias del imperio de ultramar ${ }^{53}$. No se han conservado numerosos registros de cómo se les proveería, pero los que existen son suficientes para aclarar el procedimiento adoptado. En 1693, el provincial jesuita de Goa escribió al rey. En su exposición, explicó que la Compañía de Jesús tenía 25 parroquias en Salsete, cuyo gobierno "habían confiado siempre los reyes de Portugal a los religiosos de la Compañía, dejando al cuidado y vigilancia de sus prelados no sólo la elección de los párrocos", sino también el aumento de dichas iglesias, disposición que, según el provincial, fue reiterada en 1648 por el rey Juan IV $^{54}$. Es decir, en las iglesias de la Compañía de Jesús, quien proveía a los sacerdotes eran los superiores de los jesuitas, sin ninguna interferencia del rey, como patrón, o del obispo como la más alta autoridad eclesiástica de la diócesis.

La misma práctica fue adoptada por los franciscanos en Bardez y Ceilán. En 1617, en esta gran isla integrada en la diócesis de Cochín, había 53 iglesias y el obispo sólo proveía dos de ellas en clérigos seculares. El resto estaba en manos de los franciscanos que libremente proveían los vicarios ${ }^{55}$. Dos años después, además, los franciscanos se quejaron de que el obispo les inquietaba por estas iglesias. En la Mesa da Consciência, en Lisboa, se confirmó que estas iglesias "estaban exentas del ordinario", es decir, del obispo, y que lo habitual era los franciscanos proveyeran los beneficios parroquiales sin interferencia del prelado de Cochín. Sin embargo, se advirtió que estas provisiones debían recaer en personas que conocieran los idiomas locales y sólo podían hacerse desde la India y nunca desde la sede del orden en Roma, o incluso desde Lisboa ${ }^{56}$. En el fondo, se trataba de la aplicación del principio adoptado por los obispos para la provisión de las prebendas de los cabildos y para los

51 AAV, Congregazione Concilio, Relationes Dioecesium, vol. 481, fls. 14-14v, accesible em https://www.uc.pt/ fluc/religionAJE/fontes/docs/Malaca_1624_traduzida.pdf.

52 Mendonça, D. de: Conversions and Citizenry: Goa under Portugal 1510-1610, New Delhi, Concept Publishing, 2002, pp. 71-73.

53 Xavier y Olival, op. cit. (nota 6), p. 136.

54 AHU, Conselho Ultramarino, India, caixa 67, doc. 7.

55 BN, Pombalina, Códice 155, fl. 48.

56 BN, Pombalina, Códice 155, fl. 48v. 
beneficios de las parroquias: elegía la autoridad eclesiástica presente en el terreno. Desde Lisboa, sólo el rey podía proveer. En Brasil lo mismo ocurrió en las llamadas aldeas o misiones, donde vivían las poblaciones amerindias, la mayoría de ellas dominadas por los jesuitas.

La cuestión de los poderes otorgados a los obispos dio lugar a controversias en el caso de Angra. Debido, tal vez, a que se estaba imponiendo la práctica de que la Mesa da Consciência e Ordens examinase a los clérigos cuando la diócesis estaba vacante o cuando el obispo estaba todavía en Lisboa, la Mesa intentó extender sus poderes y exigió el escrutinio de las elecciones del obispo de Angra. Sin embargo, el regente don Henrique, defensor inflexible de la autoridad episcopal en esta cuestión, dejó claro en la carta por la que concedió autoridad al obispo Nuno Álvares Pereira para poder hacer la elección de los beneficiados cuando se fuera a residir a su diócesis, que se presentarían "sin más diligencia o examen" que el realizado por el prelado. Por esta razón, ordenó a los diputados de la Mesa da Consciência e Ordens que expidieran las cartas de presentación sólo con "la información de dicho obispo, sin ningún otro examen más" ${ }^{\prime 57}$. En noviembre de 1578, se expidió una carta idéntica al obispo Pedro Castilho ${ }^{58}$. Las elecciones de los prelados de Angra, como en las demás islas del Atlántico, iban a Lisboa para que el rey, tras consultar con la Mesa da Consciência e Ordens, autorizase la emisión de cartas de presentación. Sin embargo, en términos prácticos, la decisión de quienes serían los titulares de los beneficios correspondía a los prelados.

Las primeras constituciones sinodales conocidas de diócesis de ultramar, las de Angra (1560) y Goa (1568), datan de este periodo. En las de Angra, precisamente porque la cuestión de la provisión se fijaba mediante cartas o permisos que expresaban una voluntad real de carácter limitado, no se explicaba cómo se debían proveer los beneficios, sino que sólo se indicaba que se trataba de un derecho real, que le correspondía "como patrono de todos los beneficios de este obispado" 59 . Las de Goa, en este y otros lugares, prácticamente copian las de Angra, lo que denota que había un patrón común en estos textos, adoptados sin cambios profundos en espacios variados y con poblaciones tan diferentes como las de una isla del Atlántico o una diócesis gigantesca en Asia que servía de frontera con múltiples religiones y sistemas culturales ${ }^{60}$.

\section{Concursos según el modelo del tridentino y mercedes reales}

El patronato real no eximía a las diócesis de ultramar de las decisiones tomadas por las autoridades de la Iglesia romana. Entre ellas, y en el marco de las reformas eclesiásticas concebidas en el Concilio de Trento (1545-1563), se decidió, con el fin de asegurar que las iglesias parroquiales fueran gobernadas por clérigos "dignos e idóneos", que su elección se hiciera mediante un concurso que preveía el examen de

Cédula real del 16 de julio de 1567, ANTT, Ordem de Cristo, Chancelaria Antiga, Livro 1, fl. 120-120v, publicado en De Witte, Ch. M.: "Documents anciens des archives du chapitre d'Angra”, Lusitania Sacra, XI (1972), pp. $188-189$.

58 ANTT, Ordem de Cristo, Chancelaria Antiga, Lv. 4, fl. 115-115v.

59 Contituiçoes synodaes do bispado de Angra, Lisboa, João Blavio de Colonia, 1560, fl. 40v.

60 Constituiçoens do arcebispado de Goa, Goa, João de Endem, 1568, fl. 45. 
los méritos de los candidatos. El mismo decreto reconocía que había iglesias cuyos patronos eran laicos, y en estas circunstancias, los párrocos nombrados por las autoridades laicas no serían admitidos hasta que hubieran sido examinados y aprobados por personas nombradas para este fin por los obispos ${ }^{61}$.

Los decretos tridentinos fueron adoptados rápidamente en Portugal y en el caso de los nombramientos para las iglesias parroquiales hay pruebas claras de ello, por ejemplo en la diócesis de Viseu ${ }^{62}$. En la América española, este tipo de examen sólo llevó a cabo desde $1575^{63}$. En junio de 1568, el rey Sebastián, probablemente aconsejado por su tío abuelo, el cardenal don Enrique, envió un albalá al obispo de Angra, en el que le informaba de que "las dignidades y los beneficios de la catedral y de las iglesias del obispado de Angra se debían proveer" por "oposición", es decir, por concurso, y el obispo debía examinar a los candidatos y enviar al rey un certificado de ello, para que luego el monarca mandase expedir sus cartas de presentación. Este albalá no alteró el modelo de provisión ya adoptado, sino que sólo añadió otra pieza que reforzaba el papel de los obispos. Esta decisión, además, prueba que la Mesa da Consciência e Ordens era un lugar central para la definición de la política eclesiástica, ya que el monarca aclaró que había tomado esta decisión de acuerdo con "la determinación hecha sobre esto en la Mesa da Consciência e Ordens, donde por mi orden especial se trató de las cosas que cumplían para el buen gobierno y administración los obispados de mi obligación"

Las primeras constituciones de las diócesis de ultramar compiladas después del mencionada albalá de 1568, que fueron las de Funchal, incorporaban una explicación de cómo debían celebrarse estos concursos y los exámenes de los candidatos, y hay que admitir que las preparadas por el obispo de Brasil, Constantino Barradas, alrededor de 1605 también podrían contener referencias similares ${ }^{65}$. El procedimiento muestra que estos concursos y exámenes no se hacían a la ligera, sino que estaban bien regulados y crearon una nueva cultura. El texto de las Constituciones de Funchal recordaba el albalá de 1568, que en aquel momento estaba registrada en los archivos de la diócesis, por la que el rey Sebastián, como patrono, había impuesto "que todos los beneficios de este obispado, así curados como simples (excepto la dignidad de deán) se concedan por oposición”. En consecuencia, determinaba que "cuando cualquier beneficio curado quede vacante (...) deben ponerse en nuestro nombre los edictos públicos", dando a los candidatos diez días para solicitarlo. Todos debían ser examinados por el obispo o, si éste no podía hacerlo, por el provisor del obispado y los examinadores sinodales que los prelados se encargaban de nombrar.

${ }^{61}$ Véase la sess. XXIV, cap. XVIII, De reformat., en $O$ sacrosanto, e ecumenico concílio de Trento em latim e portuguez, Lisboa, Simão Thaddeo Ferreira, 1786, tomo II, pp. 323-331.

62 Sobre la recepción de Trento en Portugal véase Polónia, A.: "A recepção do Concílio de Trento em Portugal", en Gouveia, A. Camões; Barbosa, D. Sampaio y Paiva; J. P. (coord.): O Concílio de Trento em Portugal e nas suas conquistas. Olhares novos, Lisboa, Centro de Estudos de História Religiosa, 2014, pp. 41-58. Para Viseu véase Paiva, J. P.: “A acção dos bispos e os outros poderes”, en Paiva, J. P. (dir.): História da Diocese de Viseu, Viseu-Coimbra, Diocese de Viseu e Imprensa da Universidade de Coimbra, 2016, vol. 2, pp. 351-352.

63 Schwaller, op. cit. (nota 22), p. 136.

64 Albalá en ANTT, Ordem de Cristo, Chancelaria Antiga, Livro 1, fl. 137, publicado em De Witte, op. cit. (nota 57), pp. 206-207. Otros albalás de contenido semejante debieron haber sido expedidos para los obispos ultramarinos, como se comprueba por los ejemplos de los que se enviaron para Cabo Verde y Funchal, ambos de 1570, vease Brásio, op. cit. (nota 24), vol. III, pp. 3-4 y ANTT, Cabido da Sé do Funchal, maço 5, doc. 34, já referido por Costa, op. cit. (nota 12), pp. 89-90.

65 No se conocen copias de estas constituciones, véase Veiga, op. cit. (nota 9), p. 38. 
En el caso de la provisión de dignidades y canonjías, la inspección era llevada a cabo personalmente por el obispo.

En estos exámenes se preguntaba si los opositores tenían al menos 25 años de edad, si eran hijos legítimos, "bien acostumbrados, de buen ejemplo y fama". También era necesario comprobar, mediante certificados expedidos por los secretarios de la visita pastoral y el tribunal episcopal, que no habían sido condenados por la justicia episcopal o tenían alguna causa pendiente. Satisfecho este examen de "vida y costumbres (vita et moribus)" se examinaron por su "ciencia", siendo evaluados de latín, modo de administrar los sacramentos, conocimiento de los casos de conciencia en materia de confesión sacramental, canto y "prudencia". En esta época, aparte de la legitimidad del nacimiento, no había ninguna inspección de la llamada "limpieza de sangre". Comprobados los resultados, el prelado elegiría al "más digno, y escribirá al rey nuestro señor sobre él, para ser presentado a dicha iglesia, de acuerdo con el mencionado albalá. Y si ninguno de los examinados fuere suficiente para el beneficio vacante, se pondrá en él un cura que servirá hasta que haya personas adecuadas para rector". Esto significa que el obispo podía poveer curas, de manera interina, sin que el patrono, es decir, el rey, tuviera que pronunciarse sobre esta elección, lo de muestra que el poder de los obispos en sus diócesis era amplio ${ }^{66}$.

En 1635, fue el propio monarca quien impuso, por lo menos en Goa, que, incluso durante el período de sede vacante, todas las provisiones, incluido el decano, se hicieran utilizando el mecanismo de la oposición ${ }^{67}$. Las reglas que imponían los concursos eran claras, pero sería útil saber cómo se cumplían, tarea imposible debido a la casi total desaparición de los procesos que debían conservarse en los archivos diocesanos.

Las disposiciones sobre los concursos que emanaban de Roma restringían la capacidad de la monarquía como titular del derecho de patronato e implican que la administración de las mercedes que el rey tenía a su disposición en los territorios de ultramar a cambio de los servicios prestados por los eclesiásticos se negociasen con el episcopado o que el monarca aprovechase los períodos de sede vacante para imponer sus opciones con mayor libertad. El hecho de que los obispos fueran, en general, clientelas reales ayudó a la Corona a aprovechar las posibilidades abiertas por el patronato real ${ }^{68}$. Pero el centro político no era hegemónico en este proceso, de modo que no todos las provisiones estaban impregnadas por la lógica de la atribución de mercedes por parte de la Corona, sobre todo por la imposición de concursos, y también porque los monarcas confiaron a los obispos residentes en las diócesis la elección de la mayoría de los provistos y no quisieron amputar poderes que disminuyeran su autoridad ${ }^{69}$.

66 Constituições synodaes do Bispado do Funchal, feitas e ordenadas por D. Ieronymo Barreto, Lisboa, Antonio Ribeiro, 1585, pp. 69-70.

67 Comunicación del virrey, en 1671, que refiere una carta de 1635 en AHU, Conselho Ultramarino, Índia, caixa 45, doc. 23, fl. sin numeracion.

68 Paiva, op. cit. (nota 10), pp. 565 y 571-573.

69 En este sentido puede suscitar interpretaciones erróneas la propuesta de Aldair Rodrigues de que la provisión de catedrales y parroquias bajo el patronato real fue siempre una merced real controlada por el centro político para recompensar "los servicios prestados por los colonos a la monarquía", tanto más cuanto que, hasta mediados del siglo XVII, en muchas diócesis, los elegidos venían de Portugal, véase Rodrigues, A.: "O Padroado da Ordem de Cristo e as elites do Brasil Setecentista: análise do acesso aos benefícios eclesiásticos", Luso-Brazilian Review, 53, 1 (2016), pp. 117-119. Tanto es así que, en el estudio más profundo, con datos empíricos, que hay sobre la provisión de beneficios en las diócesis del centro-sur de Brasil (Rio de Janeiro, S. Paulo y Mariana), este 
Aun así, y a pesar de la regla de los concursos, hay noticias de que los monarcas continuaron proveyendo lugares como merced, sin siquiera someter a los agraciados a los exámenes realizados por los obispos, incluso cuando éstos residían en sus diócesis. En agosto de 1570, por ejemplo, el rey Sebastián informó al obispo de San Tomé que, como tenía buena información de un clérigo jalofo, había decidido presentarlo en una capellanía curada de la diócesis. Explicó que había sido sometido a un "examen hecho por los sacerdotes de la Compañía", eludiendo la jurisdicción episcopal, y por lo tanto, "ordenaba" al obispo que lo confirmara. ${ }^{70}$ El proceso también denota la fuerza que los jesuitas alcanzaron en el centro político, lo que se relaciona en parte con la influencia lograda allí por el ignaciano Luís Gonçalves da Câmara. En 1588, en Arguim, en la actual Mauritania, entonces territorio bajo la jurisdicción del obispo de Funchal, había un vicario, freire de la Orden de Cristo, puesto allí por el rey, tal y como sucedía en Achém (Aceh), en la isla de Sumatra, actual Indonesia, entonces bajo la jurisdicción del obispo de Malaca ${ }^{71}$. Hay que admitir que, para salvaguardar situaciones de este tipo, los monarcas hubiesen presionado en Roma. Precisamente en 1589, una deliberación de la Congregación del Concilio, institución competente en la resolución de las cuestiones relativas a la aplicación de los cánones tridentinos, decretó que los beneficios de la Orden de Cristo, como era el caso de los infra-episcopales en las diócesis de ultramar, no tenían que ser provistos por concurso, lo que los Estatutos de la Orden todavía recordaban en $1671^{72}$.

Por otra parte, en las diócesis de creación más tardía, en las que la presencia portuguesa era inestable, como en el caso del Congo/Angola, erigida sólo en 1596, durante el período de integración del reino de Portugal en la Monarquía Hispánica, se practicaban formas de provisión bastante negociadas, así como frecuentes oscilaciones en las formas de proceder, que se debían a las dificultades prácticas experimentadas en esas regiones, tanto por los agentes de la Corona como por los de la Iglesia. En 1610, el rey creó la dignidad de tesorero del cabildo y nombró al canónigo que debía ocuparlo, imponiendo al obispo que expidiese las respectivas "letras de confimación"’3. En el informe de la visita ad limina de 1619, el obispo informó de que las prebendas del cabildo eran todas provistas por el monarca, quejándose de que pocos aceptaban las dignidades y canonjías con que se les agraciaba, por tener que ir a "regiones tan distantes y tan peligrosas por el clima insalubre, debido al bajo salario". Tal vez por esta razón, cinco años antes, la Mesa de Consciência e Ordens había sugerido que el soberano de Portugal condiese al rey del Congo la presentación de las dignidades (incluido el deanato) y las canonjías de la catedral. Esta idea fue criticada por el obispo en el mismo informe de la visita ad limina, porque de esta manera, dijo, se provería a "naturales de la tierra" que no tenían las costumbres y co-

mismo autor deja bien claro que "os bispos foram peças importantíssimas no funcionamento das engrenagens do padroado na colónia no que toca aos provimentos", ver Rodrigues, A.: Igreja e Inquisição no Brasil. Agentes, carreiras e mecanismos de promoção social - século XVIII, São Paulo, Alameda, 2014, pp. 119-121. Aprovecho para agradecer a Aldair Rodrigues la lectura que ha hecho de este texto y sus sugerencias.

70 Brásio, A.: Monumenta Missionaria Africana. Africa Ocidental (1570-1599), Lisboa, Agência Geral do Ultramar, 1953, vol. III, pp. 154-155.

71 Brásio, A.: Monumenta Missionaria Africana. Africa Ocidental (1469-1599). Suplemento aos séculos XV e XVI, Lisboa, Agência Geral do Ultramar, 1954, vol. IV, pp. 478-479.

72 Rodrigues, op. cit. (nota 69, 2016), p. 125.

73 El original es un registro de la cancillería de la Orden de Cristo publicado en Brásio, A.: Monumenta Missionaria Africana. Africa Ocidental (1600-1610), Lisboa, Agência Geral do Ultramar, 1955, vol. V, pp. 567-68. 
nocimientos necesarios para desempeñar estas funciones. Sin embargo, en la misma consulta, la Mesa propuso que el vicario de Benguela fuera nombrado por el obispo que residía en Angola ${ }^{74}$.

Unos años más tarde, en 1621, una cédula real aclaraba que, durante la vacante, el gobernador tenía que notificar directamente a la Mesa da Consciência de cualquier beneficio que quedase vacante, "para proveer a las personas examinadas y aprobadas por ella, como siempre ha sido la costumbre en todos los obispados de ultramar mientras están vacantes", lo que confirma una práctica que había estado en vigor desde los años 40 del siglo anterior, cuando las diócesis estaban sin obispo, y que demuestra que, durante esos períodos, los monarcas tenían mayor margen para controlar el proceso de elección ${ }^{75}$. Además, dicha cédula añadía, que cuando los obispos estuvieran en la diócesis, podrían nombrar a quien quisieran para los beneficios, y éstos deberían ser presentados por el gobernador, de acuerdo con la práctica seguida desde que se estableció la diócesis de Goa. En 1632, el gobernador de Angola confirmó, en una información enviada a la Mesa da Consciência, que el rey había dado permiso al obispo Francisco do Soveral para proveer todos los beneficios, excepto el deán ${ }^{76}$. Y de hecho, cuatro años después, fue el monarca quien eligió y presentó al deanato. En su carta a la Mesa da Consciência a este respecto, dejó claro que quienes solicitasen este puesto por sus servicios podían hacerlo, y que la Mesa debía presentar tres candidatos al monarca, y podía añadir a esta terna de nombres otros, una señal de la ampliación de los poderes de la Mesa y de la importancia que tenía para la Corona contar con una forma de compensar a quienes le prestaba servicio ${ }^{77}$.

Sin embargo, lo más insólito en el caso de Angola fue que algunas parroquias fueran provistas por el obispo, sin la intervención del monarca o de su gobernador, porque los nominados, siempre sacerdotes nativos que conocían las lenguas indígenas, eran pagados por varios sobas, es decir, jefes de las comunidades locales ${ }^{78}$. También en Brasil había iglesias para las cuales los obispos proporcionaban párrocos "ad nutum", es decir, a discreción, sin requerir permiso real, y en esta colonia eran los feligreses o los propietarios de las capillas los que tenían que sustentar a los sacerdotes así establecidos ${ }^{79}$. Según algunas interpretaciones, en el siglo XVIII, la mayoría de las iglesias de Brasil estaría en esta situación. Menos numerosas fueron los vicarías coladas o perpetuas, cuyos clérigos eran pagados por la Corona con los

74 AAV, Congregazione Concilio, Relationes Dioecesium, vol. 50, fls. 4-6. La cita es una traducción del latín original realizada por António Guimarães Pinto, accesible en https://www.uc.pt/fluc/religionAJE/fontes/docs/ Angola_1619_traduzida.pdf e BN, Pombalina, Códice 155, fl. 79v.

75 Publicado en Brásio, A.: Monumenta Missionaria Africana. Africa Ocidental (1610-1621), Lisboa, Agência Geral do Ultramar, 1955, vol. VI, pp. 580-581.

76 Publicado en Brásio, A.: Monumenta Missionaria Africana. Africa Ocidental (1631-1642), Lisboa, Agência Geral do Ultramar, 1955, vol. VIII, p. 188.

77 Brásio, op. cit. (nota 75), vol. VI, p. 188.

78 AAV, Congregazione Concilio, Relationes Dioecesium, vol. 50, fls. 12-14, disponible en https://www.uc.pt/fluc/ religionAJE/fontes/docs/Angola_1640_traduzida.pdf.

79 Veiga, op. cit. (nota 9), p. 38 y Neves, G. Pereira das: “Clero secular”, en Silva, M. B. Nizza da: Dicionário de História da Colonização Portuguesa no Brasil, Lisboa, Verbo, 1994, 1994, col. 171-75. En este excelente texto, su autor es uno de los raros casos que llama la atención sobre el hecho de que el clero secular era "la columna vertebral de la Iglesia en la colonia", siguiendo, además, las sólidas propuestas hechas por Arlindo Rubert, especialmente en "Brasil", en Andrade, A. A. Banha de: Diccionário de História da Igreja em Portugal, Lisboa, Editorial Resistência, 1983, vol. 3, pp. 263-265 y 326-333. 
ingresos de la recaudación de los diezmos ${ }^{80}$. Es cierto que la Corona tenía puestos los ojos en los lugares más atractivos y rentables, pero el régimen de mercedes reales no era universal en el marco del patronato, y los obispos tenían fuertes poderes y discrecionalidad en la provisión de clero secular, al igual que los superiores de las órdenes religiosas en el caso de las parroquias que se encontraban bajo su tutela.

\section{Impactos de la integración de portugal en la monarquía hispánica}

La integración de Portugal en la Monarquía Hispánica no tuvo un gran impacto en el modelo de proveer a los clérigos de los cabildos e iglesias de las diócesis ultramarinas. Más aún porque, ya en 1585, el Papa aclaró que el "patronato" de los reyes de Castilla y el "padroado" de la corona de Portugal, que tenían diferentes matices, permanecían autónomos ${ }^{81}$. Aun así, durante el reinado de Felipe III, se intentó aproximar al modelo de Castilla los procedimientos adoptados en Portugal, mediante la creación de un Consejo de la India. Esto imitaba, en Portugal, el órgano central de todo el gobierno de los espacios de ultramar bajo la tutela de los monarcas de Castilla y limitaba la acción de la Mesa da Consciência e Ordens. En la Mesa se sabía, el 7 de enero de 1604, que "el nombramiento de los obispados y la provisión de los beneficios que por cualquier vía perteneciesen a Su Majestad, como maestro, pasarían y se despacharían en el Consejo de la India". ${ }^{82}$ Para evitar dudas, ya que la Mesa no estaba a favor de esta decisión, argumentando que se trataba del patronato de la Orden de Cristo y no de la Corona, el 2 de enero de 1606 se publicó una cédula real que determinaba que la provisión de obispados y beneficios eclesiásticos "que tocan las partes de ultramar" se "despacharía" en el "Consejo de la India", conforme a sus instrucciones, y que en los despachos de todos esos asuntos, que antes pasar por la Mesa da Consciência, el mencionado Consejo de la India podríae utilizar" sus normas y estilos ${ }^{83}$.

A pesar del cambio de fase, se mantuvieron los procedimientos adoptados anteriormente, como demuestra la autorización dada por el rey al gobernador de Santo Tomé para que presentara al clero que le fuese indicado por el obispo local, que estaba dispuesto a ir a residir en su diócesis, exceptuando, como ya era habitual en las diócesis de las islas del Atlántico y en Brasil, el caso del deán ${ }^{84}$. Además, la Mesa da Consciência no fue totalmente condenada al ostracismo. En 1606, por ejemplo, se pronunció sobre la petición del obispo de Funchal, entonces en Lisboa para participar en un concilio provincial, que deseaba mantener el privilegio de nombrar personas para los beneficios vacantes. A la Mesa le parecía que esta "merced" concedida a los obispos sólo se aplicaba "residiendo [ellos] personalmente en su obispado (...) y no de otra manera" 85 .

80 Lima, L. Lage da Gama: “O padroado e a sustentação do clero no Brasil colonial”, Saeculum - Revista de História, 30 (2014), p. 52 y, con informaciones rigurosas sobre la diocésis de S. Paulo, Rodrigues, op. cit. (nota 67, 2014), pp. 38-39.

$81 \quad$ Xavier e Olival, op. cit. (nota 6), p. 137.

82 ANTT, Mesa da Consicência e Ordesn, Consultas, Livro 23, fl. 7, de la segunda numeración.

83 Collecção Chronologica de Leis Extravagantes posteriores à nova compilação das Ordenações do Reino publicadas em 1603, Coimbra, Real Imprensa da Universidade, 1819, tomo I, pp. 59-61.

84 Brásio, op. cit. (nota 75), vol. VI, p. 61-63.

85 ANTT, Mesa da Consciência e Ordens, Consultas, Livro 16, fl. 65v. 
Las controversias creadas por la aparición de la nueva institución en el organigrama de la administración central de la monarquía portuguesa determinaron su fin, en mayo de 1614, lo que manifiesta cuán efímera fue su presencia en el plano de la provisión de obispados. Es probable que la Mesa da Consciência, una vez que sus poderes fueron restaurados, tratase incluso de ampliar sus competencias. Sin embargo, una cédula real expedida a favor del obispo de Funchal ordenó a los miembros de la Mesa que "con información de dicho obispo, sin más examen, hagan pasar las cartas de presentaciones o provisiones", manteniendo sin cambios el poder de los obispos ${ }^{86}$.

También fue fugaz y sin consecuencias el esfuerzo realizado por la Corona, tanto en la India como en el Brasil, para secularizar el clero de ciertas parroquias de Asia y el de las aldeas indígenas del Brasil, hasta entonces encargadas a los regulares, en consonancia con las medidas adoptadas en la América española. En enero de 1607, en una carta real al virrey de la India, se pone de manifiesto que no se había aplicado una orden anterior para que las parroquias de la isla de Goa, Bardez y Salsete fueran administradas por sacerdotes seculares, reconociendo el monarca que los religiosos cumplían "bien su oficio"87. En Brasil, las peticiones hechas desde 1603 por el gobernador de esa colonia dieron lugar a una ley de 1611, en virtud de la cual se reproduciría el modelo de las misiones jesuíticas adoptado en el Perú. Esta ley fue incluso promulgada, y determinó que estos pueblos tendrían un cura o vicario portugués, secular, que debería ser presentado por el monarca y confirmado por el obispo. Además, en los casos en que estos curas o vicarios fueran regulares, estarían sujetos a la autoridad del obispo. Pero las reservas que suscito fueron inmensas, e incluso el obispo del Brasil Constantino Barradas, en 1605, se había pronunciado en contra de esta solución, por lo que tuvo poco efecto ${ }^{88}$.

En lugar de estas iniciativas, la adopción de normas discriminatorias para los descendientes de judíos, musulmanes, negros o mulatos, es decir, en el lenguaje más violento y racista de entonces, los que tenían "sangre infecta" o "defecto de color", sería duradera y tendría consecuencias en la configuración social del clero de ultramar. El conjunto de normas relativas a la "limpieza de la sangre" apareció tarde en Portugal y se intensificó durante el período de la unificación de las coronas ibéricas ${ }^{89}$. Desde mediados del siglo XVI se ampliaron las restricciones para la admisión en diversas instituciones estatales y eclesiásticas basadas en la "mancha" de sangre, pero fue en la década de 90 de este siglo cuando se generalizaron las investigaciones sobre la "limpieza de sangre"

Por lo que toca al ingreso en el clero secular y la provisión de prebendas en las catedrales, las primeras disposiciones datan de 1588. El papa Sixto V ordenó enton-

ANTT, Cabido da Sé do Funchal, maço 5, doc. 35.

87 Pato, R. A. de Bulhão: Documentos remetidos da India ou Livros das Monções, Lisboa, Academia Real das Sciencias, vol. I, p. 84

88 Este asunto fue muy bien aclarado por Feitler, B.: "Continuidades e rupturas da Igreja na América Portuguesa no tempo dos Áustrias. A importância da questão indígena e do exemplo espanhol”, en Cardim, P.; Costa, L. Freire y Cunha, M. Soares (org.): Portugal na Monarquia Hispânica. Dinâmicas de integração e conflito, Lisboa, CHAM, 2013, pp. 211-220.

89 Bethencourt, F.: “A Inquisição”, en Azevedo, C. Moreira (dir.): História Religiosa de Portugal, Lisboa, Círculo de Leitores, vol. 2, p. 53.

90 Los mejores trabajos sobre el tema son Olival, F.: "Rigor e interesses: os estatutos de limpeza de sangue em Portugal", Cadernos de Estudos Sefarditas, 4 (2004), principalmente pp. 153-160, y Figueirôa-Rego, J. de, "A honra alheia por um fio". Os estatutos de limpeza de sangue nos espaços de expressão ibérica (sécs. XVIXVIII), Lisboa, Fundação Calouste Gulbenkian e FCT, 2011, pp. 66-68. 
ces la suspensión de las provisiones hechas por él para las catedrales hasta que los obispos averiguasen la ascendencia de los nominados. Sin embargo, el documento decisivo fue el breve Decet Romanum Pontificem, emitido por Clemente VIII el 18 de octubre de 1600, que también tuvo implicaciones en las tierras donde los monarcas tenían el patronato, que impuso la exclusión de los descendientes de los judíos de todas las prebendas o beneficios que tuvieran cura de almas ${ }^{91}$.

En Portugal, las primeras constituciones diocesanas que recogieron estos principios fueron las de Portalegre (1632), seguidas pronto por las del arzobispado de Lisboa (1640), que estuvieron en vigor en Brasil hasta 1707, y en Maranhão incluso más tarde. En éstas, además de la exclusión de los descendientes de los judíos, quedaban proscritos del acceso al sacerdocio los esclavos y los que no tuviesen la piel blanca ${ }^{92}$. Los efectos de estas normas se fueron arraigado, y son evidentes en las únicas nuevas constituciones diocesanas compiladas en las diócesis de ultramar en el siglo XVIII, las derivadas del sínodo de Bahía de 1707. Allí, recordando las disposiciones papales antes mencionadas, se imponía que, para la recepción de la prima tonsura, que daba acceso al estado clerical, se investigue si los candidatos "tienen parte de la nación hebrea o de cualquier otra nación infectada o de negros o mulatos". Y para acceder a los beneficios, los candidatos debían someterse a investigaciones de "limpieza de sangre" 93 .

Las disposiciones papales tuvieron consecuencias ya en 1603, cuando el rey autorizó al obispo de Brasil, Constantino Barradas, como de costumbre, a elegir, después de los concursos, los beneficios de las catedrales y vicarías del patronato de la Orden de Cristo, con una advertencia que lo diferenciaba de situaciones similares en el pasado: el obispo sólo podía elegir a los "viejos cristianos", es decir, a los que tenían la "sangre limpia" "Tenía una intención similar la cédula real dirigida al obispo de San Tomé, que en 1628 recomendó que las personas nombradas no fueran "por ningún medio, por muy remoto que sea, nuevos cristianos", y que los obispos debían "hacer exámenes e investigaciones muy claras" ${ }^{95}$. Al año siguiente, cuando el Ayuntamiento de Río de Janeiro pidió al rey que diera preferencia a los clérigos nacidos en la tierra, otro factor cada vez más relevante, el monarca aceptó la recomendación de que los elegidos debían tener "limpieza de sangre" ". Además de la "sangre", las elecciones debían considerar la naturalidad de los clérigos. En Funchal, desde 1513 hubo presión local para que los elegidos nacieran en la diócesis; en Brasil los habitantes de la Bahía la reclamaron a principios del siglo XVII; el Ayuntamiento de Goa y el vicario general de la diócesis de Meliapor también lo pedirán en $1665^{97}$.

Estas normas de segregación restringían el campo de reclutamiento del clero en las diócesis de ultramar e imponían que, en los concursos para la provisión de pre-

91 Almeida, F. de: História da Igreja em Portugal, Barcelos, Livraria Civilização Editora, 1968, vol. II, p. 59.

92 Lo recuerda sabiamente Oliveira, A. J. Machado de: "A administração do sacramento da ordem aos negros na América Portuguesa: entre práticas, normas políticas e episcopais (1702-1745)", Revista de História, Juiz de Fora, 21, 2 (2015), pp. 421-422.

93 Constituiçoens primeyras do arcebispado da Bahia, Lisboa, Pascoal da Sylva, 1719, pp. 93 y 211-212.

94 BN, Pombalina, Códice 155, fl. 124.

95 Publicado en Brásio, A.: Monumenta Missionaria Africana. Africa Ocidental (1622-1630), Lisboa, Agência Geral do Ultramar, 1955, vol. VII, pp. 539-541.

96 BN, Pombalina, Códice 155, fl. 15.

97 Véase, respectivamente, Costa, op. cit. (nota 12), p. 85, BN, Pombalina, Códice 155, fl. 14v y AHU, Conselho Ultramarino, Índia, caixa 47, doc. 193. 
bendas o iglesias, hubiese exámenes de "vita et moribus" pero también "de genere". Sin embargo, esto no impidió que el clero nativo accediese a estos lugares. En 1618, siguiendo órdenes reales, el virrey de la India envió un albalá a todos los obispos portugueses de Asia para que siguieran proveyendo "clérigos nativos de la tierra" que conocieran los idiomas hablados por sus feligreses, para evitar, sobre todo, las confesiones que se hacían con intérpretes ${ }^{98}$. Tampoco impidieron, mucho más tarde en Río de Janeiro, entre 1702 y 1721, que 32 de los 347 clérigos ordenados fuesen sospechosos de tener "sangre judía", otros 30 fuesen negros, 8 amerindios y 3 mestizos, hijos de negros y nativos americanos ${ }^{99}$.

\section{Largos períodos de sede vacante, refuerzo del papel de la mesa da consciência e ordens, mantenimiento de las prerrogativas de los obispos}

A finales de 1640, se inició una nueva coyuntura en Portugal marcada por el fin de la integración del reino en la Monarquía Hispánica y el establecimiento de una nueva dinastía, cuyo primer rey fue don João IV. En este ciclo de rupturas en el centro político, acompañado de un contexto de relaciones muy difíciles entre Portugal y Roma, no hubo cambios profundos en el proceso de provisión de los beneficios eclesiásticos en las diócesis no europeas. Sin embargo, como es habitual en períodos similares, hubo dudas e intentos de fortalecer el poder de varios organismos y agentes que buscaban posicionarse en el nuevo escenario político.

En 1642 se creó el Conselho Ultramarino para centralizar el gobierno de los territorios del imperio. Su regimiento establecía que la comunicación dirigida al rey por los obispos y otros agentes debía ser enviada al Consejo, pero que el nuevo organismo no se ocuparía de la provisión de los beneficios de las iglesias, que seguirían pasando por la Mesa da Consciência e Ordens ${ }^{100}$. Sin embargo, surgieron dudas debido a los nuevos circuitos de las decisiones reales. En 1643, la Mesa da Consciência subrayó que "le correspondía consultar los asuntos eclesiásticos de la India", solicitando que, después de la partida de las naves, el secretario real encargado de estos despachos enviara a la Mesa las resoluciones tomadas por el rey Juan IV, "para conocer la noticia de ellas"101. En 1646, la misma Mesa tenía la intención de ser escuchada en relación con los oficios de las diócesis, como el de provisor o vicarios general, pero el rey, tras consultar a algunos canonistas y teólogos, recordó que, desde 1514, la jurisdicción espiritual de la Orden de Cristo se había extinguido, y que sólo poseía el patronato de las iglesias y de los cabildos ${ }^{102}$.

En esta época, el rey avocó a elección del deán de la catedral de Goa ${ }^{103}$. En 1643,

98 Cédula del virrey don João Coutinho, de 28 de noviembre de 1618, publicada en Rivara, J. H. da Cunha: Archivo Portuguez-Oriental. Fascículo 6, New Delhi, Asian Educational Services, 1992, pp. 1159-1160.

99 Datos recogidos del excelente y rigoroso estudio de Ferreira, F. Vinagre: O clero secular no bispado do Rio de Janeiro e o múnus episcopal de D. Francisco de S. Jerônimo (1702-1721), Rio de Janeiro, [s.n.], 2016 ("dissertação de mestrado em História", Universidade Federal do Estado do Rio de Janeiro), pp. 54-56, 65 y 70 .

100 Boletim do Conselho Ultramarino. Legislação Antiga, Lisboa, Imprensa Nacional, 1867, vol. I, pp. 240-241.

101 BN, Pombalina, Códice 155, fl. 13v.

102 BN, Pombalina, Códice 155, fl. 51v.

103 No pude determinar si, a principios del siglo XVII, como en Brasil, el rey también elegía al deán en las diócesis de Asia. 
en un proceso que demuestra la cultura instalada, al considerar estos lugares como mercedes administradas por la Corona para recompensar a sus servidores, Juan IV eligió al deán de Goa para que sirviera como prelado en la administración eclesiástica de Mozambique. Al tratar de su sustitución, el virrey escribió a Lisboa, sugiriendo que el rey proveyese como nuevo deán al eclesiástico que ocupaba el lugar de chantre. Lo hizo "porque le pareció justo", porque el arzobispo y el cabildo se lo habían pedido, y por "el servicio que [el propuesto] ha hecho" en varios oficios de la Iglesia $\mathrm{y}$, sobre todo, como oidor del tribunal real ${ }^{104}$.

Mientras tanto, en Brasil, en 1644, el nuevo gobernador quiso asegurarse de que conservaba los poderes de sus predecesores, destinados a presentar los beneficiados que le sugerían los obispos, lo que le fue negado ${ }^{105}$. La medida anticipaba el mayor cambio que la nueva dinastía iba a adoptar: las provisiones, después de los exámenes hechos en Brasil y las sugerencias recibidas de los obispos, siempre tenían que ser consultadas en la Mesa da Conciencia.

Entre 1640 y 1670 , debido a los impasses y cuasi el bloqueo de las relaciones entre Portugal y Roma, las diócesis de ultramar se quedaron sin obispos. Gobernadas por los cabildos, el deán generalmente desempeñaba un papel decisivo, lo que explica también la lucha que la Corona mantuvo para monopolizar la elección de esta dignidad. En este problemático escenario, una consulta de la Mesa da Consciência, de marzo de 1651, determinó que, durante los periodos de sede vacante, los cabildos debían realizar las funciones que la monarquía había confiado a los obispos residentes en las diócesis desde 1538, es decir, la elección del clero de las catedrales y de las iglesias. Los cabildos debían celebrar concursos in situ e indicar sus elecciones, que, sin embargo, se examinarían en Lisboa, en la Mesa, a excepción de los curas amovibles de nombramiento anual. Además, desde Lisboa, también se podrían proveer beneficios ${ }^{106}$.

Esta regla ya se aplicaba en Goa, poco después de la muerte del arzobispo fray Francisco dos Mártires, por determinación de una carta real en marzo de 1654. En el caso de los beneficios con cura de almas, el cabildo exponía a los virreyes o gobernadores sus opciones y eran estos los que presentaban a los elegidos. En los otros beneficios llamados "simples", sobre todo en las prebendas más rentables de las catedrales, los provistos por el cabildo tenían que "enviar a buscar al reino sus cartas de confirmación en los primeros barcos que vinieren de ese Estado, después de la provisión hecha, para que se pasen por mí [el rey]"107.

Este nuevo sistema tardó en consolidarse. En 1655, el cabildo de Goa se quejó de que el virrey había hecho presentaciones que iban más allá de las sugerencias de los canónigos. La regente Luisa de Gusmão recriminó por ello al virrey y anuló estas provisiones. El cabildo, sintiéndose sin poder, también presionó para que se suspendiera la decisión sobre algunos de los beneficios que se proveían en Lisboa. Entre las razones principales, el cabildo afirmó que había recibido del reino la provisión de "un canarín" y "un cojo de nacimiento que no podía ni siquiera estar de pie en el altar", lo que iba en contra de las normas canónicas y los preceptos de "limpieza de sangre". Un "escándalo", según el cabildo. Además, dos personas habían sido

104 AHU, Conselho Ultramarino, India, caixa 25, doc. 64.

105 BN, Pombalina, Códice 155, fl. 125a.

106 Figueirôa-Rêgo y Olival, op. cit. (nota 11), pp. 132-133.

107 AHU, Conselho Ultramarino, India, caixa 45, doc. 23, fl. 16v-17. 
provistas de la misma prebenda, lo que "es un puro desorden en las provisiones"108.

En 1661, otro virrey sugirió a Lisboa los inconvenientes de delegar esta importante tarea al cabildo, porque en Goa, los canónicos formaban partidos y eran muy jóvenes, tomando malas decisiones, y constató que el hecho de haber elecciones hechas unas en Lisboa y otras en la India creaba situaciones complicadas. Mientras tanto, en abril de 1661, la regente autorizaba a los gobernadores de la India a presentar en su nombre a las personas que les habían sido propuestas por los arzobispos o cabildos $^{109}$. En las décadas siguientes, en Goa siguió habiendo resistencias a la hora de aceptar presentaciones que llegaban de Portugal e incluso de celebrar concursos. Un ejemplo de esto es la queja del virrey contra el hecho de que el cabildo hiciera los nombramientos sin que mediasen concursos, en 1672, y la negativa del cabildo, en 1685, de confirmar la presentación de algunos párrocos hecha en Lisboa, alegando una formalidad insignificante: la presentación no especificaba el nombre de los párrocos que habían muerto y a los que los nuevos reemplazaban ${ }^{110}$.

En el caso del Brasil, desde 1660 las elecciones para la provisión de beneficios hechas en las diócesis pasaron a ser objeto de posteriores consultas en la Mesa da Consciência ${ }^{111}$. Además, cuando un beneficio quedaba vacante, los anuncios de los respectivos concursos se publicaban en la colonia y en Lisboa, y los candidatos que residían en Portugal eran examinados en la Mesa da Consciência ${ }^{112}$. Este precepto generó resistencia por parte de los cabildos, que retrasaban el envío de la información sobre las vacantes a Lisboa, tratando de ganar tiempo y avanzar en los concursos a nivel local, lo que la Mesa, vigilante, trató de impedir ${ }^{113}$. En enero de 1670, alegando estos retrasos, y con un obispo de Salvador ya nombrado, pero todavía residente en Lisboa, la Mesa proveyó una serie de beneficios vacantes en "pretendientes que las pedían sin esperar más a los concursos" que debían enviarse desde el Brasi1114.

A partir de 1670, hubo de nuevo obispos en las diócesis de ultramar y se reanudó la práctica iniciada en Goa en 1538. Cuando partían de Lisboa, los prelados recibían una provisión real que les autorizaba, mediante un concurso y los exámenes habituales, incluido el de "limpieza de sangre", a indicar al rey los clérigos que debían proveerse. Se conocen varios registros de este tipo para las diócesis de Brasil, Goa, Funchal, Cabo Verde y Macao desde 1671, en los que se indica expresamente que los obispos sólo podían proveer los lugares que quedasen vacantes después de su llegada a los territorios y se mantiene la obligación de que todas las decisiones se remitiesen a Lisboa para ser consultadas en la Mesa da Consciência, que se convirtió en el lugar estratégico donde se evaluaban los procesos y distribuían las mercedes ${ }^{115}$.

Los gobernadores de Brasil, Angola, Cabo Verde y Santo Tomé ya no realizarían las presentaciones en nombre del monarca, aunque algunos lo reivindicasen, pero sin éxito. Incluso en la lejana Macao, al menos para las prebendas en el cabildo, las propuestas del obispo iban a Lisboa para ser consultadas en la Mesa, como atestigua

\footnotetext{
108 AHU, Conselho Ultramarino, India, caixa 45, doc. 23, fl. 17v-20.

109 AHU, Conselho Ultramarino, India, caixa 44, doc. 141.

110 Vease, repectivamente, AHU, Conselho Ultramarino, India, caixa 52, doc. 78 y BN, Pombalina, Códice 155 , fl. 14.

111 Este tema ya ha sido muy bien explicado en Xavier y Olival, op. cit. (nota 6), pp. 131 y 154-155.

112 Varios ejemplos, entre 1662 y 1693 en BN, Pombalina, Códice 155, fl. 125v.

113 BN, Pombalina, Códice 155, fl. 13v.

114 BN, Pombalina, Códice 155, fl. 125v.

115 BN, Pombalina, Códice 155 , fl. 65,123 v y $125 \mathrm{v}$.
} 
un documento de $1710^{116}$. Por otra parte, con el fin de garantizar lugares para que el rey los distribuyese, en las nuevas diócesis creadas en Brasil en 1676-1677 (Olinda, Río de Janeiro y Maranhão), quedó claro que era el monarca quien elegiría a todas las dignidades y canónigos cuando se instituyese la catedral, y sólo en las siguientes vacantes transmitiría este poder a los obispos, con la excepción del deanato que quedaba reservado al monarca ${ }^{117}$.

La obligación de que los procesos fuesen tramitados por la Mesa generó ocasionales constestaciones. En 1678, el obispo de Angola rechazó a dos canónigos presentados por el rey, alegando que eran "mulatos" y "criminales". La Mesa respondió que "ser mulato no era un impedimento", que había certificados que probaban que no tenían culpas ante la justicia eclesiástica y que el "obispo no era suficiente para privarlos de la merced" 118 . En Brasil, en 1723, el cabildo de Río de Janeiro, sede vacante, también se negó a una provisión hecha en concurso realizado por la Mesa, aunque ésta mantuvo la indicación regia ${ }^{119}$. Más tarde, en 1752, el obispo de Mariana se negó, en un primer momento, a confirmar y colar a un vicario que había sido provisto en Portugal ${ }^{120}$.

Las Constituciones de Bahía confirmaron la práctica iniciada unos 40 años antes. En el Libro III, título XXI, se reconoció que, en cuanto a la provisión de las iglesias, el poder de los obispos de ultramar estaba limitado por el "patronato", y que sólo les competía "la colación y confirmación del clero que presenta Su Majestad". Sin embargo, esta limitación había sido mitigada por el "celo, la piedad y la suma religión" del monarca, que "generalmente nos permite usar este privilegio, atendiendo más a la utilidad de las iglesias y al bien de sus vasallos, que a este su dominio supremo", es decir, el patronato. En consecuencia, el rey "concede a los obispos la facultad de proveer a las iglesias, precediendo concurso, de párrocos idóneos, dignos de ejercer las graves obligaciones del oficio pastoral". Después de explicar los concursos y exámenes que se celebraban, se aclara que de entre los "aprobados elegiremos [el arzobispo] el más digno", que "propondremos a Su Majestad para que le mande expedir carta de presentación conforma a sus provisiones reales que suele conceder a los obispos de ultramar, y por esa carta será confirmado y colado de acuerdo con el derecho". Añadían que, para evitar largas vacantes en las iglesias con cura de almas, al tener que esperar a que los procesos fuesen a Lisboa, el obispo podría poner ecónomos hasta que se confirmase la provisión del beneficio ${ }^{121}$. En 1718, el arzobispo responsable de estas Constituciones, Sebastião Monteiro da Vide, trató también de resucitar el sistema de que sus propuestas fueran sólo confirmadas por el gobernador de Bahía, lo que le fue concedido como excepción, signo de la consideración de la monarquía por la autoridad episcopal ${ }^{122}$.

\footnotetext{
116 AHU, Conselho Ultramarino, Macau, caixa 2, doc. 77, gracias a Kevin Soares por esta información.

117 ANTT, Mesa da Consciência e Ordens, Livro 304, fl. 17-17v; agradezco a Fernanda Olival por esta información.

118 BN, Pombalina, Códice 155, fl. 14 e 81.

119 BN, Pombalina, Códice 155, fl. 14v.

120 Fonseca, C. Damasceno: "Freguesias e capelas: instituição e provimento de igrejas em Minas Gerais", en Feitler, B., y Souza, E. Sales: A Igreja no Brasil. Normas e práticas durante a vigência das Constituições Primeiras do Arcebispado da Bahia, São Paulo, UNIFESP, 2011, pp. 440-441.

121 Constituiçoens, op. cit. (nota 93), pp. 209-211. Es imprudente y errónea la interpretación que concluye que este procedimiento supondría una gran limitación para los obispos, y que éstos se resistieron a su aplicación, sugerida por Fonseca, op. cit. (nota 120), pp. 430-432 y 440-441.

122 BN, Pombalina, Códice 155, fl. 123v.
} 
Testimonios referentes a varias diócesis confirman que, aunque las elecciones del obispo debían ser confirmadas por el rey, tras el parecer de la Mesa da Consciência, las propuestas de los prelados eran respetadas. La mayoría de las provisiones dependían de las elecciones episcopales y no de las mercedes regias logradas por la presentación en la Mesa da Consciência de hojas de servicios y la importancia de los buenos padrinos. De hecho, en ninguna diócesis de Portugal los obispos tuvieron tanta influencia en la elección del clero parroquial como en las diócesis no europeas, aunque en ellas no tenían el derecho de patronato. En la diócesis de Coimbra, los obispos tenían el patronato de sólo el 9\% de las parroquias, y el 91\% restante correspondía a diversos patronos que, en estos casos, imponían a clérigos que los prelados debían confirmar y colar. En Viseu, los obispos tenían el derecho de presentación de alrededor del $18 \%$ de las parroquias de la diócesis ${ }^{123}$.

Para la diócesis de Funchal, se cuenta con un libro que servía para registrar los "nombramientos hechos a Su Alteza por los obispos para la provisión de las dignidades, canonjías, vicariatos y beneficios de las iglesias", que abarca el período comprendido entre 1675 y 1748. El modelo de los asientos es uniforme, como se percibe en el ejemplo de la provisión del vicariato de San Martín en 1713. El obispo informó de que había abierto el concurso cuando el lugar quedó libre por el fallecimiento del anterior propietario, especificó los nombres de los oponentes, los exámenes realizados por los examinadores sinodales con un cuestionario idéntico para todos ellos y facilitó el nombre del ganador. Como tenía "las partes y requisitos necesarios, y era cristiano-viejo, de buena vida y costumbres", el obispo "lo nombró" a "Vuestra Majestad, para que, siendo servido, le mande expedir la carta de presentación". Estas misivas llegaron al rey, como se observa por las anotaciones al margen de muchos registros, a través de la Mesa da Consciência e Ordens. Entre los cientos de previsiones que se llevaron a cabo allí, no hay indicios de que alguno de ellos haya sido rechazado, y los casos de personas elegidas en Lisboa sin que el obispo hubiese hecho la propuesta son muy raros, como ocurrió con la provisión de dos capellanes para la colegiata de Câmara de Lobos en $1685^{124}$.

En la diócesis de Olinda, en 1730, el obispo José Fialho informó que de las 45 iglesias parroquiales de la diócesis, 32 tenían párrocos confirmados por él. Las vacantes se sacaron a concurso y el obispo "después de elegir el más adecuado tras el examen, presenta su nombre ante el rey, que también, de la misma manera que, por derecho de patronato, ordena que se expida el diploma de presentación de los canónigos, confirma al candidato presentado por el obispo". Cabe señalar que los poderes episcopales incluían la presentación en las iglesias con "párrocos colocados a discreción de los ordinarios", como era el caso de las que no tenían vicarios colados ${ }^{125}$.

En todas las diócesis debe haber habido libros para registrar las colaciones y otras provisiones que hacían los obispos, en los que se podrían comprobar rigurosamente las prácticas adoptadas. Sólo conozco una copia de este tipo para la diócesis de Ma-

123 Carvalho, J. Ramos de y Paiva, J. P.: “A diocese de Coimbra no século XVIII. População, oragos, padroados e títulos dos párocos", Revista de História das Ideias, 11 (1989), p. 226 y Nunes, J.: "O padroado”, en Paiva, op. cit. (nota 62), p. 25.

124 Arquivo e Biblioteca da Madeira, Arquivo do Paço Episcopal do Funchal, no 41, microfilme 681, principalmente fl. 55 e 19. Agradezco a Bruno Costa que me haya indicado esta fuente.

125 AAV, Congregazione Concilio, Relationes Dioecesium, vol. 596, fl. 100v. La cita es una traducción del latín original realizada por António Guimarães Pinto, accesible en https://www.uc.pt/fluc/religionAJE/fontes/docs/ Olinda_1730_traduzida.pdf. 
ranhão, que comprende entre 1740 y $1747^{126}$. Sin embargo, dado el marco normativo y los numerosos indicios de cómo se producían estas colaciones, se puede admitir que la forma de proceder registrada aquí fue la que se siguió en las otras diócesis de ultramar. Para desempeñar su función "con mayor autoridad", el obispo fray Manuel da Cruz había recibido una carta real que le confería la facultad de nombrar "dignidades, canónigos y vicarios de los que quedasen vacantes después de su residencia no siendo en personas de la nación de los cristianos nuevos", con excepción del arcediano de la catedral, que era aquí la primera dignidad del cabildo. La carta explica el alcance y la discrecionalidad de las opciones del obispo y, en una nota para el presidente y los diputados de la Mesa da Consciência, se dice: "encargo (el rey) y [ordeno] que con el nombramiento de dicho obispo sólo sin [ninguna] otra diligencia, se les pase en mi nombre la carta de presentación firmada por mí a las personas nombradas por dicho obispo" 127 .

En el libro de "Registro de provisiones" se encuentran las etapas del proceso. Tomemos el ejemplo de la provisión del tesorero de la catedral. En julio de 1745, el rey lo presentó, por la buena información que le había dado el obispo, tras consultar con la Mesa de Consciência. El 12 de noviembre, en San Luis de Maranhão, el obispo recibió la carta de presentación que le entregó el clérigo presentado, la registró y expidió la confirmación en la "forma del estilo". En ella, el prelado deja claro que considerando la "capacidad, virtud, letras y buen proceder del Reverendo Doctor João Marques da Silva (...) tuvimos a bien de informar de él para una canonjía de la citada catedral, y siendo servido Su Majestad (...) de dicha información de presentar en ella al mencionado Reverendo Doctor", el prelado lo confirmó. A esto siguió el ritual de la colación, en la catedral, donde el obispo colocó el anillo en su dedo y el birrete en su cabeza, el 15 de noviembre. En otros casos, el prelado presentó y confirmó vicarios sin ninguna interferencia de Lisboa, como ocurrió en 1742, cuando proveyó al párroco y vicario de Icatu, ya que era una iglesia "sin colación, pero ad tempus", en la que existía la "costumbre y la posesión por parte de nuestros predecesores de proveer". Asimismo, presentó y confirmó los beneficios en las capillas de institución privada, a petición de su propietario, como fue el caso del capellán de la hacienda de Cumá. Esta tenía 400 esclavos y su dueño había instituido la iglesia para el servicio de su casa y para que los esclavos tuvieran alguien que les administrarse los sacramentos, a saber, la misa y la extremaunción ${ }^{128}$.

Por último, hay registros de vicarios presentados en Lisboa por el rey, sin que el obispo haya interferido, pues sólo se le requirió para confirmar la presentación real. Esto ocurrió en 1742, con la presentación del vicario de Moucha, en la que el rey dice que "por las buenas informaciones que tengo del padre João Rodrigues Covette" y dada "su suficiencia y letras, vida, costumbres y servicio que ha hecho en dicho obispado", tiene por bien "hacerle la merced de la citada iglesia (...) y de presentarlo en ella". Así, ordenó al obispo que "le expidiese sus cartas de confirmación en la

126 En el tribunal eclesiástico de Rio de Janeiro hay un códice semejante que abarca el período comprendido entre 1772 y 1823, Rodrigues, op. cit. (nota 67, 2014), p. 93.

127 Véase una copia de esta cédula real en Auto crime de injúria atroz feita ao bispo Manuel da Cruz pelo vigário Pedro Gonçalves da Cruz, en Arquivo Público do Estado do Maranhão (APEM), Acervo da Arquidiocese, doc. 4597, fl. sin numeración. Agradezco a Pollyanna Muniz que me haya indicado esta fuente.

128 APEM, Acervo da Arquidiocese, Livro de registo de provisões feitas elo bispo Manuel da Cruz (1740-1747), doc. 82, principalmente fl. 100v-101v, 26-27 e 23-23v; agradezco a Pollyanna Muniz que me haya indicado esta fuente. 
forma acostumbrada, mencionando cómo lo ha confirmado por mi presentación para la preservación del derecho de la Orden de Cristo" 129 . Y así lo hizo el obispo, en un proceso que comenzó en Lisboa en mayo de 1740 y se concluyó con la colación en Maranhão en julio de 1742, un retraso que podría tener implicaciones en la vida religiosa de las comunidades si los obispos no proporcionaban curas o ecónomos para suplir las ausencias.

Estos asientos prueban que las cartas de presentación emitidas por la cancillería de la Orden de Cristo en Lisboa implicaban el pago de 2500 réis por el registro y 850 réis para los oficiales implicados, lo que sugiere que también había intereses materiales que salvaguardar con la medida, decretada en 1660, de que las provisiones de los beneficios simples y curados deberían ir siempre a consulta a la Mesa da Consciência. Cuando el beneficiado era confirmado y colado en la diócesis, también pagaba 300 réis por el "sello" de la cancillería episcopal ${ }^{130}$.

En Goa, el arzobispo Inácio de Santa Teresa confirmó que las iglesias de su diócesis confiadas a clérigos seculares, eran provistas "tras un concurso, con el permiso del rey-patrón, por el obispo, y por él mismo, como ordinario, establecidos y colados". El prelado tenía una noción muy detallada del número total de parroquias existentes, no sólo en la isla de Goa y en las zonas contiguas de Bardez y Salsete, sino también en Canara, Angediva, Sonda, Chaul, Baçaim, Taná, Damão, Terapor, Maim, Caranjá, Bombay y Diu, prueba de que tenía en el archivo de la mitra registros de las sus provisiones. En total, identificó la significativa cantidad de 226 iglesias parroquiales, algunas de ellas colegiatas. De ellas, 149 se proveían con clérigos seculares, incluyendo los 25 de Salsete, que antes estaban a cargo de los jesuitas. Las 77 restantes se encontraban confiadas a miembros del clero regular, especialmente a los franciscanos (46), que administraban todas las de Bardez, seguidos por los jesuitas que todavía tenían iglesias en Sonda, Baçaim y Taná (13). El resto se dividía entre los dominicos (6), cinco de ellos en Goa, los misioneros apostólicos (4), los carmelitas (4) y los agustinos (3) $)^{131}$.

Aunque los obispos no tenían la hegemonía, ya que había lugares que el rey podía proveer sin consultarlos, el alcance del poder episcopal, tal como se demostró, era enorme y aún se perpetuó cuando, en 1745, se crearon las diócesis de Mariana y São Paulo. El obispo de Mariana, por ejemplo, recibió una carta real en mayo de 1745, que le autorizaba a "nombrar a las dignidades y canónigos de la misma catedral y a instituir canónicamente a los (...) nombrados, aunque los nombramientos no estuvieren confirmados por mí (el rey)". Competía entonces de los nominados "pedir mi confirmación por parte del Tribunal de la Mesa da Consciência e Ordens". De hecho, como ya se ha estudiado, fue el obispo quien "nombró, coló y dio posesión" al nuevo cabildo, quizás con la excepción del arcediano ${ }^{132}$. De la misma manera, en

129 APEM, Acervo da Arquidiocese, Livro de registo de provisões feitas pelo bispo Manuel da Cruz (1740-1747), doc. 82 , fl. $32 \mathrm{v}-33 \mathrm{v}$.

130 Este ingreso ya fue objeto de la consulta de la Mesa, en 1632, cuando se pidió al obispo de Brasil que no sugiriera los beneficiados directamente al gobernador, sino a la Mesa, debido a los ingresos que esto generaría, BN, Pombalina, Códice 155, fl. 125.

131 AAV, Congregazione Concilio, Relationes Dioecesium, vol. 367, fl. 44-61. La cita es una traducción del latín original realizada por António Guimarães Pinto, accesible en https://www.uc.pt/fluc/religionAJE/fontes/docs/ Goa_1734_traduzida.pdf.

132 Boschi, C. C.: O cabido da Sé de Mariana (1745-1820). Documentos básicos, Belo Horizonte, Fundação João Pinheiro, 2011, pp. 13-14, 28 e 78-79. 
São Paulo, fue el prelado quien eligió el cabildo, a pesar de que recibió presiones de las élites locales, lo que resultó en que nueve de los 14 prebendados que nombró fuesen paulistas ${ }^{133}$.

\section{Se amplía el dominio del centro político y las provisiones sin concurso}

A mediados del siglo XVIII, en el contexto del refuerzo del poder absoluto del monarca y de las innumerables medidas que restringían los privilegios de la Iglesia y del clero, se amplió la capacidad de la Corona para utilizar el patronato real como instrumento al servicio de su política de mercedes con los que la servían. Esto significó restricciones en el alcance del poder episcopal y, sobre todo, un aumento del número de clérigos provistos al margen de los concursos, a través de peticiones presentadas directamente a la Mesa da Consciência en Lisboa. Aldair Rodrigues estudió bien este ciclo, analizando con criterio el discurso de los peticionarios y el tipo de servicios que presentaban, para el caso de Brasil, en este momento la región central de la política imperial portuguesa y aquella para la que subsiste el mejor conjunto de fuentes documentales conservadas ${ }^{134}$.

Los candidatos, en sus peticiones, como era habitual en la cultura de la época y para la provisión de mercedes de diversa índole, no sólo explicaban sus servicios personales, por ejemplo si habían sido visitadores, vicarios u otros, sino también los de sus familiares. En 1777, el pretendiente al lugar de arcediano en la catedral de Bahía, destacó que era hermano del deán, que su padre había prestado servicios al rey, remontándose a un abuelo que, en el siglo XVII, había servido en la guerra contra los holandeses y había ido como prisionero a Holanda ${ }^{135}$. Este sistema contribuyó, por un lado, a que la Corona mantuviera en su dependencia a algunos poderosos locales y, al mismo tiempo, a que ciertas familias gozasen de gran poder en ciertas regiones y acaparasen lugares cruciales en los ayuntamientos, la milicia, los tribunales y la Iglesia, en este caso, principalmente en los cabildos de las catedrales.

Hay informes de que al menos el obispo de Mariana, fray Manuel da Cruz, fue crítico con este tipo de provisiones a petición. En 1750, manifestó al fray Gaspar da Encarnação que era consciente de que el rey, aunque autorizaba a los prelados a indicarle la persona que debía ocupar los beneficios, "puede proveer extraordinariamente en las iglesias de las conquistas a quien le parezca". Sin embargo, a otro interlocutor

133 Rodrigues, op. cit. (nota 2014), pp. 45-47. Ya no sigo este estudio cuando sostiene que, desde finales del siglo XVII, los beneficios se disputaban entre las élites coloniales y la Corona, en el marco de la economía de mercedes, véase pp. 42-43. La atención a la naturalidad del provisto, especialmente para los cabildos, comenzó mucho antes.

134 Rodrigues, op. cit. (nota 67, 2014), pp. 55-76. Igualmente útil para el caso de la práctica y la cultura de las provisiones en el cabildo de Salvador, después de 1755, pero con imprecisiones en el caso de épocas anteriores, además de interpretaciones que no secundo, especialmente la noción de que el patronato real, en el plano de las provisiones de beneficios, constituyó un obstáculo a la acción de los obispos, véase Silva, H. Ribeiro da: "O cabido da Sé de Salvador da Bahia: quadro institucional e mecanismos de acesso (1755-1799)", en Souza, E. Sales Souza; Marques, G., y Silva, H. Ribeiro da (org.): Salvador da Bahia. Retratos de uma cidade atlântica, Salvador-Lisboa, EDUFBA-CHAM, 2016, pp. 163-189.

135 ANTT, Mesa da Consciência e Ordens, Ordem de Cristo, Padroados do Brasil, maço 1, fl. sin numeración (imagem 1166). 
confesó que tenía "poca fe en estas provisiones extraordinarias logradas por empeños y grandes sumas"136.

La investigación puede extenderse a otras diócesis brasileñas, pero a juzgar por lo ocurrido en Río de Janeiro, Mariana y São Paulo en la segunda mitad del siglo XVIII, en la mayoría de los casos la Mesa da Consciência e Ordens y el monarca confirmaron la elección del obispo. Sólo en 19 de 128 beneficios presentados, el 15\% del total, el rey nombró a alguien por "decreto", aunque no es posible certificar que todos fueron posteriormente confirmados y colados por los obispos ${ }^{137}$.

En términos prácticos, cambió poco. Los obispos siguieron recibiendo cédulas reales cuando salieron para la diócesis, que les autorizaban, tras realizar concursos, a indicar al rey a través de la Mesa da Consciência su elección, como puede verse en el nombramiento de vicario de Maragogipe, que hizo el arzobispo de Bahía en marzo de 1770. En el margen superior izquierdo de esta petición, los diputados de la Mesa registraron, en abril de 1771, "que se pase carta al nominado", aceptando la propuesta del obispo ${ }^{138}$. Esto era así, aunque la Mesa no siempre estaba al tanto de los permisos que el rey concedía a los prelados. Antes de esta provisión, en 1766, la Mesa, refiriéndose a una propuesta del arzobispo al monarca, aludía al hecho de que el prelado hacía "mención a la facultad real que tenía de Su Majestad para nombrar iglesias vacantes, y como la Mesa no tiene noticia de esta facultad que dice el arzobispo, pide la Mesa reverentemente a Su Majestad que se sirva mandarle comunicar su resolución real para que en la expedición de órdenes pueda acertar con su gusto y servicio"139. Duda que explica por qué, en algunos casos, entre la solicitud del obispo y la orden final de la Mesa da Consciência hubo un lapso de más de tres años y a veces incluso se perdieron documentos.

Las mayores rupturas, además del aumento del número de casos que se proveyeron a petición de los clérigos candidatos a los beneficios, fueron un albalá de 29 de agosto de 1766 y el decreto de fecha 25 de mayo de 1773. Éste abolió la distinción entre cristianos nuevos y viejos y contribuyó a la desaparición de los exámenes "de genere" que, desde principios del siglo XVII, se habían convertido en cruciales ${ }^{140}$. La cédula real de 1766 determinaba que en la provisión de beneficios, simples y curados, se diera prioridad a los naturales de las diócesis ${ }^{141}$. Por eso, en este mismo año, el albalá que autorizaba al obispo de Mariana a proveer los beneficios vacantes en su diócesis, junto a la fórmula habitual, hacía explícito que debía proponer a "naturales de ese vuestro obispado"142. Cabe señalar que los prelados, para eludir esta regla, que dificultaba la colocación de los beneficios de la clientela que traían del reino, utilizaban ellos mismos el mecanismo de petición al rey. Esto sucedió, por ejemplo, en 1773, cuando el rey José I escribió a la Mesa da Consciência comunicando que "en vista de lo que me era presentado por parte del arzobispo de Bahía, decidí nombrar a

136 La importancia de estos pasajes ya ha sido reconocida por Rodrigues, op. cit. (nota 69, 2014), p. 61.

137 Rodrigues, op. cit. (nota 69, 2014), p. 125

138 ANTT, Mesa da Consciência e Ordens, Ordem de Cristo, Padroados do Brasil, maço 1, fl. sin numeración.

139 ANTT, Mesa da Consciência e Ordens, Ordem de Cristo, Padroados do Brasil, maço 1, fl. sin numeración (imagem 151).

140 El decreto está publicado en Silva, A. Delgado: Collecção da legislação Portugueza desde a última compilação das Ordenações, Lisboa, Typographia Maigrense, 1828, vol. 2, pp. 672-678.

141 El original en ANTT, Cabido da Sé do Funchal, maço 5, doc. 22, véase también Rodrigues y Olival, op. cit. (nota 31), pp. 57

142 Rodrigues, op. cit. (nota 67, 2014), p. 52. 
su sobrino Bernardo de Figueiroa en el asiento de canónigo de la catedral de la misma ciudad", pidiéndole que se le ordenaran hacer los correspondientes despachos, que la Mesa ejecutón ${ }^{143}$.

Al final del gobierno de José I, los concursos para la provisión de beneficios ya no se celebraban en las diócesis y estaban centralizados en Mesa da Consciência. Esto sería una brutal limitación de la autoridad y el margen de acción de los obispos. Sin embargo, no duró mucho, ya que con la muerte del rey José I (1777), y la inmediata pérdida de poder del marqués de Pombal, la reina María I, en 1781, volvería a conceder a los obispos el privilegio de proponerle nombres para los cabildos e iglesias de sus diócesis, poniendo fin a la posibilidad de que la Mesa da Consciência sugiriera propuestas alternativas ${ }^{144}$.

\section{Consideraciones finales}

El sistema de provisión de los beneficios eclesiásticos infra-episcopales en las diócesis portuguesas de ultramar, en el contexto del patronato real, evolucionó entre los siglos XVI y XVIII. Como todo derecho de patronato, tenía cuatro componentes que se cumplían en una secuencia inalterable: la presentación del beneficiado, la confirmación, la colación y la posesión. La especificidad del patronato real radicaba en que los reyes de Portugal, en su calidad de gobernadores de la Orden de Cristo, tenían derecho a presentar todos los beneficios, desde el deán de la catedral hasta los párrocos de las iglesias instituidas por la Corona. Sin embargo, los monarcas, al no ser una autoridad eclesiástica, no podían realizar por sí mismos ninguna de las otras etapas. Estas fueron siempre ejercidas por los obispos, por los cabildos de las diócesis cuando la mitra estaba vacante, o por los superiores de las religiones (franciscanos, jesuitas, dominicos, agustinos) a quienes el rey, siempre amparado en el derecho de patronato, concedió la administración de algunas iglesias, especialmente en Asia.

El aspecto crítico del sistema es saber quién elegía al individuo que se presentaría. La Corona trató de mantener en su poder la indicación de la principal dignidad del cabildo, el deán, aunque hasta principios del siglo XVII, al menos en Goa y Bahía, autorizó a los obispos residentes allí a hacerlo. Esto supuso una gran merced para sus servidores, dado el estatus del lugar y las rentas que tenía asociabas. Además, los deanes o arcedianos de algunas diócesis establecidas en el siglo XVIII, por regla general, residían en las diócesis, de modo que cuando un obispo moría y hasta que otro era provisto, se hacían cargo del gobierno de la diócesis, convirtiéndose en piezas cruciales de la afirmación del poder de la monarquía, al igual que los obispos, pues que eran clientelas elegidas por el rey.

Sin embargo, este estudio muestra que desde que los obispos de ultramar comenzaron a residir en sus diócesis en 1538, el rey Juan III y sus sucesores sin excepción les concedieron el privilegio de nombrar al rey el eclesiástico al que el monarca debía presentar. Este modelo, inspirado en parte en lo que se había hecho en Madeira cuando se creó la diócesis, al dar a un vicario residente la responsabilidad de esta elección, comenzó con la partida del primer obispo a Goa en 1538 y se consolidó

143 ANTT, Mesa da Consciência e Ordens, Ordem de Cristo, Padroados do Brasil, Maço 1, fl. sin numeración (imagem 189).

144 Lima, op. cit. (nota 80), p. 52 y Xavier y Olival, op. cit. (nota 6), pp. 154-155. 
con la ida del primer obispo de Brasil a Salvador. Los reyes lo hicieron, fundamentalmente, por tres razones: porque confiaban en los prelados que elegían, lo que constituía otra faceta del derecho de patronato que el papado les había concedido en 1514; porque querían que los obispos tuvieran autoridad y reconocían que la selección del clero diocesano era esencial para ello; porque eran conscientes de que a distancia tendrían grandes dificultades para conocer a las personas y los problemas locales, lo que era decisivo para hacer buenas elecciones que permitieran el normal funcionamiento de la vida religiosa y la difusión y el arraigo del cristianismo en sus territorios. Hay que señalar que, excluyendo el caso de la diócesis de Funchal hasta 1554, hasta aproximadamente 1651, cuando las diócesis quedaban vacantes, la presentación de los clérigos no se confiaba a los cabildos, sino a los virreyes o gobernadores de los territorios que actuaban en nombre del rey. En este momento, debido a los largos períodos de sede vacante y a las problemáticas relaciones con la Santa Sede, se decidió que los cabildos podían nombrar directamente al virrey o al gobernador para que después estos hiciesen la presentación.

Además de a los obispos, el mismo monarca, Juan III, también concedió la elección de quienes debían ser presentados a los superiores de las órdenes religiosas. Este fue el caso especialmente en Asia, y en menor medida en el Brasil. Esta opción fue el resultado: de la falta de clero secular disponible para ir a las diócesis de ultramar, especialmente en el siglo XVI; de la conciencia del compromiso y la formación que recibían los regulares, e incluso de la mayor vocación que mostraron en las misiones de difusión de la fe entre las poblaciones no cristianas; del poder de las órdenes y congregaciones religiosas en el propio centro político. Así, en las iglesias a cargo de los regulares, todas las etapas del proceso de provisión permanecieron en la misma institución. Esta opción, sobre todo desde la clausura del Concilio de Trento (1564), daría lugar a crecientes problemas por la afirmación de la jurisdicción episcopal, y constituiría un obstáculo para la plena afirmación del poder de los obispos en sus diócesis.

En casos muy concretos, como ocurrió en la diócesis de Congo/Angola, y sobre todo debido a las dificultades de afirmar la presencia portuguesa en la región, el monarca permitió que la elección fuera realizada por las autoridades locales, como el rey de Congo y algunos sobas.

Este modelo sufrió pequeños ajustes hasta la década de 1670. Uno de ellos fue la obligación, a partir de 1568, de que los obispos celebraran concursos, en la forma decretada por el Concilio de Trento, para determinar el mejor candidato, y sólo entonces indicarlo al rey, para que éste lo presentara. El otro fue la introducción de pruebas para determinar la "limpieza de sangre" de los candidatos, aplicadas a partir de 1600, que a mediados del seiscientos, ya incluían restricciones en el acceso al sacerdocio y, por consiguiente, en los beneficios eclesiásticos de los individuos que no eran blancos.

El mayor ajuste de este modelo fue resultado de la intromisión y el fortalecimiento de las competencias de un nuevo organismo central de la monarquía, la Mesa da Consciência e Ordens. Desde mediados del siglo XVI, en las diócesis de las islas del Atlántico, y después de 1640 en las diócesis de Asia, en el Congo/Angola y en Brasil, sobre todo cuando se trataba de los llamados beneficios simples (que no implicaban la cura de almas), las indicaciones de los obispos se remitían a esta institución, que podía pronunciarse sobre ellas antes de llegar a la decisión real. Hasta mediados del siglo XVIII, siempre se tuvo cuidado en aclarar que las indicaciones de los obispos debían ser respetadas por la Mesa, pero no siempre fue así. Después de 1660, comen- 
zaron a abrirse concursos, tanto en las diócesis como en Lisboa, pero sólo después de 1750 se intensificó la práctica de hacer peticiones directamente a la Mesa alegando servicios, y así se eludían las elecciones locales de los obispos.

Este sistema, que se aplicó ampliamente en todas las diócesis de ultramar, fue determinado por el centro político, con adaptaciones locales ocasionales, y aseguraba que los monarcas tuvieran el control del clero, con la excepción de lo que sucedía en las iglesias confiadas a las órdenes regulares. También les permitía utilizar estos lugares de la Iglesia como mercedes para los eclesiásticos que les servían mejor, aunque el pago (mantenimiento o congrua) que sus titulares recibían de la Corona fuese tan tenue $\mathrm{y}$, a veces, pagado con tanta dificultad, que podía considerarse más como una carga que como una merced. La gracia real se practicaba sobre todo en el caso de la primera dignidad de las catedrales, en las canonjías con ocasión de la primera provisión después de la creación de las diócesis y durante las sedes vacantes. Además, en cualquier momento el rey podía presentar directamente a los obispos los individuos que deseaba nombrar, incluso sin respetando los concursos que Trento había defendido. Pero hasta aproximadamente 1750 esas situaciones eran raras, y tras esa fecha no alcanzaron proporciones relevantes.

En la práctica, los obispos, por concesión regia, escogieron a la mayoría de los provistoss, sin restricciones especiales. Ocasionalmente recibían sugerencias de los monarcas o conjugaban sus elecciones con sus representantes locales, virreyes y gobernadores, pero esto no les impedía de actuar. Además, disponían, sobre todo en Brasil, a medida que se intensificaba el aumento de la población y la penetración en el interior, de un número impresionante de lugares en iglesias y capillas no vinculadas a la Corona, párrocos ecónomos y curas anuales, a los que elegían, presentaban y colaban sin ninguna interferencia real. Además, en comparación con lo que ocurría en el reino, los obispos de ultramar tenían incluso más derechos prácticos de presentación que sus homólogos en las diócesis de Portugal, y esta prerrogativa les fue dada por los monarcas, lo que amplió su significado y dio apoyo desde el brazo secular a las decisiones de los obispos de ultramar. Además, aunque no fueran los obispos quienes eligieran al candidato, la última palabra era siempre suya, ya que no había ninguna presentación real que pudiera tener efecto sin la confirmación de la autoridad eclesiástica competente. En ningún caso.

Desde el punto de vista de la concesión de beneficios clericales, el patronato real era un instrumento más para el ejercicio de la cultura de la mercede, pero no impidió la injerencia pontificia en el gobierno de las diócesis, ni fue causa de la reducción, y menos aún de la aniquilación del poder de los obispos, con excepción de las parroquias que se confiaban a los regulares. Pero incluso éstas, en el siglo XVIII en Goa, eran sólo el 33\% del total de parroquias de la diócesis. En Portugal, ningún obispo tuvo nunca derechos de presentación en el 66\% de las parroquias de su diócesis.

\section{Bibliografía}

Almeida, F. de: História da Igreja em Portugal, Barcelos, Livraria Civilização Editora, 1968, vol. II.

Bethencourt, F.: "A Igreja", en Bethencourt, F. y Chaudhuri, K. (dir.): História da Expansão Portuguesa, Lisboa, Círculo de Leitores, 1998, vol. 1, pp. 369-386. 
Bethencourt, F.: “A Inquisição”, en Azevedo, C. Moreira (dir.): História Religiosa de Portugal, Lisboa, Círculo de Leitores, vol. 2, 2000, pp. 95-131.

Boletim do Conselho Ultramarino. Legislação Antiga, Lisboa, Imprensa Nacional, 1867, vol. I.

Boschi, C. C.: O cabido da Sé de Mariana (1745-1820). Documentos básicos, Belo Horizonte, Fundação João Pinheiro, 2011.

Brásio, A.: Monumenta Missionaria Africana. Africa Ocidental (1532-1569), Lisboa, Agência Geral do Ultramar, 1953, vol. II.

Brásio, A.: Monumenta Missionaria Africana. Africa Ocidental (1570-1599), Lisboa, Agência Geral do Ultramar, 1953, vol. III.

Brásio, A.: Monumenta Missionaria Africana. Africa Ocidental (1469-1599). Suplemento aos séculos XV e XVI, Lisboa, Agência Geral do Ultramar, 1954, vol. IV.

Brásio, A.: Monumenta Missionaria Africana. Africa Ocidental (1600-1610), Lisboa, Agência Geral do Ultramar, 1955, vol. V.

Brásio, A.: Monumenta Missionaria Africana. Africa Ocidental (1610-1621), Lisboa, Agência Geral do Ultramar, 1955, vol. VI.

Brásio, A.: Monumenta Missionaria Africana. Africa Ocidental (1622-1630), Lisboa, Agência Geral do Ultramar, 1955, vol. VII.

Brásio, A.: Monumenta Missionaria Africana. Africa Ocidental (1631-1642), Lisboa, Agência Geral do Ultramar, 1955, vol. VIII.

Carvalho, J. Ramos de y Paiva, J. P.: “A diocese de Coimbra no século XVIII. População, oragos, padroados e títulos dos párocos”, Revista de História das Ideias, 11 (1989), pp. 175-268.

Collecção Chronologica de Leis Extravagantes posteriores à nova compilação das Ordenações do Reino publicadas em 1603, Coimbra, Real Imprensa da Universidade, 1819, tomo I.

Constituiçoens primeyras do arcebispado da Bahia, Lisboa, Pascoal da Sylva, 1719.

Constituições synodaes do Bispado do Funchal, feitas e ordenadas por D. Ieronymo Barreto, Lisboa, Antonio Ribeiro, 1585.

Corpo Diplomático Portuguez contendo os actos e relações políticas e diplomáticas de Portugal com as diversas potencias do mundo desde o século XVI até aos nossos dias, Lisboa, Typographia da Academia Real das Sciencias e Imprensa Nacional, 1862-1959, 15 vols.

Costa, B. Abreu da: O estado eclesiástico na Madeira: o provimento de benefícios (séculos $X V$-XVII), [s.1.], [s.n.], 2013 ("dissertação de mestrado em História", Universidade de Coimbra).

De Witte, Ch. M.: Les lettres papales concernant l'expansion portuguaise au XVIe siècle, [s.1.], Nouvelle Revue de Science Missionaire, 1986.

De Witte, Ch. M.: "Les bulles pontificales et l'expansion portuguaise au XVème siècle", extrait de la Revue d'Histoire Ecclésiastique, Louvain, 1958.

De Witte, Ch. M.: "Documents anciens des archives du chapitre d'Angra", Lusitania Sacra, XI (1972), pp. 129-253.

Documentos históricos. Provimentos seculares e ecclesiásticos 1540-1559, Rio de Janeiro, Ministério da Educação e Saúde - Biblioteca Nacional, 1937, vol. XXXV.

Documentos históricos. Provimentos seculares e ecclesisticos 1559-1577, Rio de Janeiro, [s.n.], 1937, vol. XXXVI.

Feitler, B.: "Continuidades e rupturas da Igreja na América Portuguesa no tempo dos Áustrias. A importância da questão indígena e do exemplo espanhol”, en Cardim, P., Costa, 
L. Freire y Cunha, M. Soares (orgs.): Portugal na Monarquia Hispânica. Dinâmicas de integração e conflito, Lisboa, CHAM, 2013, pp. 203-230.

Fernández Terricabras, I.: "El Patronato Real en la América Hispana: fundamentos y prácticas", en Xavier, Â.; Palomo, F. y Stumpf, R. (org.): Monarquias Ibéricas em Perspectiva Comparada (séculos XVI-XVIII): dinâmicas imperiais e circulação de modelos administrativos, Lisboa, Imprensa de Ciências Sociais, 2018, pp. 97-122.

Ferreira, F. Vinagre: O clero secular no bispado do Rio de Janeiro e o múnus episcopal de D. Francisco de S. Jerônimo (1702-1721), Rio de Janeiro, [s.n.], 2016 ("dissertação de mestrado em História”, Universidade Federal do Estado do Rio de Janeiro).

Figueirôa-Rego, J. de, “A honra alheia por um fio”. Os estatutos de limpeza de sangue nos espaços de expressão ibérica (sécs. XVI-XVIII), Lisboa, Fundação Calouste Gulbenkian e FCT, 2011.

Figueirôa-Rego, J. de y Olival, F.: “Cor da pele, distinções e cargos: Portugal e os espaços atlânticos portugueses (séculos XVI a XVIII)", Tempo, 15, 30 (2011), pp. 115-145.

Fonseca, C. Damasceno: "Freguesias e capelas: instituição e provimento de igrejas em Minas Gerais", en Feitler, B., y Souza, E. Sales: A Igreja no Brasil. Normas e práticas durante a vigência das Constituições Primeiras do Arcebispado da Bahia, São Paulo, UNIFESP, 2011, pp. 425-452.

Gonçalves, S.: Primeira parte da história dos religiosos da Companhia de Jesus e do que fizeram com a divina graça na conversão dos infieis a nossa santa fee catholica nos reynos e provincias da India Oriental, Coimbra, Atlântida, 1957, vol. 1.

Jacques, R.: De Castro Marim à Faifo. Naissance et development du padroado portugais d'Orient des origines à 1659, Lisboa, Fundação Calouste Gulbenkian, 1999.

Lima, L. Lage da Gama: “O padroado e a sustentação do clero no Brasil colonial”, Saeculum - Revista de História, 30 (2014), pp. 47-62.

Marcocci, G.: A consciência de um império. Portugal e o seu mundo, sécs. XV a XVII, Coimbra, Imprensa da Universidade de Coimbra, 2012.

Mendonça, D. de: Conversions and Citizenry: Goa under Portugal 1510-1610, New Delhi, Concept Publishing, 2002.

Morna, O. M. de Freitas: As bulas de criação da diocese do Funchal, Funchal, Secretaria Regional da Economia, Turismo e Cultura, 2015.

Neves, G. Pereira das: “Clero secular”, en Silva, M. B. Nizza da: Dicionário de História da Colonização Portuguesa no Brasil, Lisboa, Verbo, 1994, col. 171-75.

Nunes, J.: “O padroado", en Paiva, J. P. (dir.): História da Diocese de Viseu, Viseu-Coimbra, Diocese de Viseu e Imprensa da Universidade de Coimbra, 2016, vol. 2, pp. 25-31.

O sacrosanto, e ecumenico concílio de Trento em latim e portuguez, Lisboa, Simão Thaddeo Ferreira, 1786.

Olival, F.: "Rigor e interesses: os estatutos de limpeza de sangue em Portugal", Cadernos de Estudos Sefarditas, 4 (2004), 151-182.

Oliveira, A. J. Machado de: “A administração do sacramento da ordem aos negros na América Portuguesa: entre práticas, normas políticas e episcopais (1702-1745)”, Revista de História, Juiz de Fora, 21, 2 (2015), pp. 415-442.

Paiva, J. P.: Os bispos de Portugal e do império. 1495-1777, Coimbra, Imprensa da Universidade de Coimbra, 2006.

Paiva, J. P.: “A acção dos bispos e os outros poderes", en Paiva, J. P. (dir.): História da Diocese de Viseu, Viseu-Coimbra, Diocese de Viseu e Imprensa da Universidade de Coimbra, 2016, vol. 2, pp. 319-479. 
Paiva, J. P.: "Les évêques à la cour du roi sous Manuel I ${ }^{\text {er }}$ et Jean III du Portugal (14951577)", Revue d'Histoire Ecclésiastique, 111, 1-2 (2016), pp. 61-79.

Paiva, J. P.: "1514. Uma religião para o mundo. Padroado régio e uma diocese pluricontinental”, en Fiolhais, C.; Franco, J. E. y Paiva, J. P. (dir.): História Global de Portugal, Lisboa. Temas e Debates, 2020, pp. 353-359.

Paiva, J. P.: "Trabalho mais para que não se pervertam os brancos do que para a conversão dos negros. Pedro Fernandes, bispo de Salvador da Bahia (1551-1556), entre Paris, Lisboa, Goa, Cabo Verde e Brasil”, Varia História, 37, 73 (2021), pp. 17-52.

Pato, R. A. de Bulhão: Documentos remetidos da India ou Livros das Monções, Lisboa, Academia Real das Sciencias, vol. I.

Pizzorusso, G.: "Il Padroado régio Portoghese nella dimensione "globale" della Chiesa Romana. Note Storico-Documentarie con particolare riferimento al Seicento", en Pizzorusso, G., Platania, G. y Sanfilippo, M. (a cura di): Gli archivi della Santa Sede come fonte per la storia del Portogallo in Età Moderna. Studi in memoria di Carmen Radulet, Viterbo, Sette Città, 2012, pp. 157-199.

Polónia, A.: “A recepção do Concílio de Trento em Portugal”, en Gouveia, A. Camões; Barbosa, D. Sampaio y Paiva; J. P. (coord.): O Concílio de Trento em Portugal e nas suas conquistas. Olhares novos, Lisboa, Centro de Estudos de História Religiosa, 2014, pp. 41-58.

Rego, A. da Silva: Documentação para a História das Missões do Padroado Português do Oriente. Índia, Lisboa, Agência Geral das Colónias, 1951, vol. II.

Rivara, J. H. da Cunha: Archivo Portuguez-Oriental. Fascículo $5^{\circ}$ que contem documentos varios do século XVI. $1^{a}$ parte, Nova Goa, Imprensa Nacional, 1865.

Rivara, J. H. da Cunha: Archivo Portuguez-Oriental. Fascículo 6, New Delhi, Asian Educational Services, 1992.

Rodrigues, A.: Igreja e Inquisição no Brasil. Agentes, carreiras e mecanismos de promoção social - século XVIII, São Paulo, Alameda, 2014.

Rodrigues, A.: "O Padroado da Ordem de Cristo e as elites do Brasil Setecentista: análise do acesso aos benefícios eclesiásticos”, Luso-Brazilian Review, 53, 1 (2016), pp. 117-137.

Rodrigues, A. y Olival, F.: "Reinóis versus naturais nas disputas pelos lugares eclesiásticos do Atlântico português: aspectos sociais e políticos (século XVIII)", Revista de História (São Paulo), 175 (2016), pp. 25-67.

Rubert, A.: "Brasil", en Banha de Andrade, A. A.: Diccionário de História da Igreja em Portugal, Lisboa, Editorial Resistência, 1983, vol. 3, pp. 263-265 y 326-333.

Schwaller, J. F.: The Church and Clergy in Sixteenth-Century Mexico, Albuquerque, University of New Mexico Press, 1987.

Silva, A. Delgado: Collecção da legislação Portugueza desde a última compilação das Ordenações, Lisboa, Typographia Maigrense, 1828, vol. 2

Silva, H. Ribeiro da: O clero catedralício português e os equilíbrios sociais do poder (15641670), Lisboa, Centro de Estudos de História Religiosa, 2013.

Silva, H. Ribeiro da: "O cabido da Sé de Salvador da Bahia: quadro institucional e mecanismos de acesso (1755-1799)", en Sales Souza, E., Marques, G., y Silva, H. Ribeiro da (orsg.): Salvador da Bahia. Retratos de uma cidade atlântica, Salvador-Lisboa, EDUFBA-CHAM, 2016, pp. 163-189.

Veiga, E. de Andrade: Os párocos no Brasil no período colonial. 1500-1822, Salvador, Universidade Católica de Salvador, 1977.

Xavier, Â. Barreto y Olival, F.: “O padroado da coroa de Portugal: fundamentos e práticas”, en Xavier, Â.; Palomo, F. y Stumpf, R. (orgs.): Monarquias Ibéricas em Perspectiva 
Comparada (séculos XVI-XVIII): dinâmicas imperiais e circulação de modelos administrativos, Lisboa, Imprensa de Ciências Sociais, 2018, pp. 123-160. 